

\title{
Transport properties of pyroclastic rocks from Montagne Pelée volcano (Martinique, Lesser Antilles)
}

Marie-Lise Bernard, Maria Zamora, Yves Géraud, Georges Boudon

\section{To cite this version:}

Marie-Lise Bernard, Maria Zamora, Yves Géraud, Georges Boudon. Transport properties of pyroclastic rocks from Montagne Pelée volcano (Martinique, Lesser Antilles). Journal of Geophysical Research : Solid Earth, 2007, 10.1029/2006JB004385 . insu-01288783

\section{HAL Id: insu-01288783 \\ https://hal-insu.archives-ouvertes.fr/insu-01288783}

Submitted on 15 Mar 2016

HAL is a multi-disciplinary open access archive for the deposit and dissemination of scientific research documents, whether they are published or not. The documents may come from teaching and research institutions in France or abroad, or from public or private research centers.
L'archive ouverte pluridisciplinaire HAL, est destinée au dépôt et à la diffusion de documents scientifiques de niveau recherche, publiés ou non, émanant des établissements d'enseignement et de recherche français ou étrangers, des laboratoires publics ou privés. 


\title{
Transport properties of pyroclastic rocks from Montagne Pelée volcano (Martinique, Lesser Antilles)
}

\author{
Marie-Lise Bernard, ${ }^{1,2}$ Maria Zamora, ${ }^{1}$ Yves Géraud, ${ }^{3}$ and Georges Boudon ${ }^{4}$ \\ Received 10 March 2006; revised 23 September 2006; accepted 10 October 2006; published 5 May 2007.
}

[1] The hydraulic and electrical properties of pyroclastic rocks have been investigated in laboratory on a representative sampling of Montagne Pelée (Martinique, France) deposits with renewed interest in geophysical applications. This sampling covers all the lithologic units of this volcano: lava dome and lava flows, pumices from ash-andpumice fall and flow deposits, lava blocks from block-and-ash flow and Peléean "nuées ardentes" deposits, scoriae from scoria flow deposits. The connected porosity varies over a wide range from 3 to $62 \%$. The unconnected porosity is important only on pumices where it can reach $15 \%$. The permeability covers more than 5 orders of magnitude, ranging from $10^{-16}$ to $35 \times 10^{-12} \mathrm{~m}^{2}$. The higher values are obtained on lava blocks and the scoriae, even if these rocks are less porous than the pumices. The formation factor ranges from 7 to 1139. The transport properties of these rocks are slightly correlated with porosity. This indicates that these properties are not only controlled by the connected porosity. To connect the transport properties to the textural characteristics of the pore network of pyroclastic rocks, different models, based on geometrical considerations or percolation theory, were tested. The pore access radius distribution and the tortuosity control the transport properties of pyroclastic rocks. Consequently, the models (electric and hydraulic) based on the concept of percolation (e.g., the models of Katz and Thompson), apply better than the equivalent channel model of Kozeny-Carman. In addition, the difference in transport properties observed on lava blocks and pumices confirms that the mechanisms of degassing and vesiculation are different for these two types of rock.

Citation: Bernard, M.-L., M. Zamora, Y. Géraud, and G. Boudon (2007), Transport properties of pyroclastic rocks from Montagne Pelée volcano (Martinique, Lesser Antilles), J. Geophys. Res., 112, B05205, doi:10.1029/2006JB004385.

\section{Introduction}

[2] Electrical and magnetic variations have been clearly measured and have been correlated with the volcanic activity on several volcanoes such as Mount Ruapehu (New Zealand) [Johnson and Stacey, 1969], La Soufrière (Guadeloupe, Lesser Antilles.) [Pozzi et al., 1979], Montagne Pelée (Martinique, Lesser Antilles) [Zlotnicki et al., 1986, 1987, 1998], Piton de la Fournaise (Réunion, France) [Zlotnicki and Le Mouël, 1988, 1990; Zlotnicki et al., 1993; Malengrau et al., 1994], Izu-Oshima (Japan) [Sasai et al., 1990], Unzen (Japan) [Hashimoto and Tanaka, 1995], Etna (Italy) [Del Negro et al., 1997]. These variations are presently monitored on various volcanoes and, in particular,

\footnotetext{
${ }^{1}$ Équipe Géomatériaux et Environnement, Institut de Physique du Globe de Paris, CNRS UMR4 7154, Paris, France.

${ }^{2}$ Now at Département de Géophysique, Institut Français du Pétrole, Rueil-Malmaison, France.

${ }^{3}$ Institut de Physique du Globe de Strasbourg, Strasbourg, France.

${ }^{4}$ Équipe de Volcanologie, Institut de Physique du Globe de Paris, CNRS UMR4 7154, Paris, France.

Copyright 2007 by the American Geophysical Union. 0148-0227/07/2006JB004385\$09.00
}

on the three main French active volcanoes (La Soufrière, Montagne Pelée, Piton de la Fournaise).

[3] Deep water circulation is thought to play a major role in the variations of the electrical properties [see Ishido and Mizutani, 1981; Bernabé, 1998; Michel and Zlotnicki, 1998; Revil et al., 2003]. However, the interpretation of the electrical resistivity or spontaneous potential surveys requires a good characterization of the electrical properties and the hydraulic properties of the common materials found on volcanoes. Permeability is an important hydraulic parameter influencing the movement of fluids within volcanic edifices.

[4] Well log measurements are largely used to improved hydrocarbon reservoir characterization. However, such data remain uncommon on volcanoes or geothermal areas [Rabaute et al., 2003], the main reason being the relatively high cost of the coring operation. Consequently the advanced knowledge on rock physics at the laboratory scale must be used more extensively, to better understand physical properties of volcanic rocks and to improve our ability to interpret geophysical anomalies on volcanoes.

[5] Moreover, permeability measurements on volcanic rocks, combined with information on their vesicularity and pore space structure, provide insight into the conditions of vesiculation and fragmentation of magma [Sparks, 1978; 
Sparks and Brazier, 1982]. As an example, differences in permeability and pore networks of volcanic clasts from Plinian falls and pyroclastic flows have been related to changes in degassing process [Thomas et al., 1994; Gardner et al., 1996; Kaminski and Jaupart, 1998; Villemant and Boudon, 1998; Saar and Manga, 1999; Klug and Cashman, 1994, 1996; Klug et al., 2002; Rust and Cashman, 2004]. However, during the postemplacement stage of volcanic rocks, different processes can modify their original petrophysical characteristics [Fisher, 1998; Flint, 2003; Flint and Selker, 2003].

[6] The explosive volcanoes of the subduction zones, the most dangerous ones, are mainly made of pyroclastic rocks. Unfortunately, little attention has been paid on the physical properties of these very common volcanic rocks. There are few laboratory studies concerning the transport properties of volcanic rocks, and particularly pyroclastic rocks [Eichelberger et al., 1986; Klug and Cashman, 1994, 1996; Whitham and Sparks, 1986; Keller, 1989; Fisher, 1998; Tait et al., 1998; Saar and Manga, 1999; Jouniaux et al., 2000; Yven, 2001; Le Pennec et al., 2001; Vanorio et al., 2002; Melnik and Sparks, 2002; Klug et al., 2002; Flint, 2003; Flint and Selker, 2003; Rust and Cashman, 2004; Sruoga et al., 2004]. Most of these studies focus on permeability. Electric conductivity and permeability properties of a small data set composed by 11 samples from Montagne Pelée have been previously presented by Jouniaux et al. [2000], whose paper was dedicated to streaming potential measurements on Montagne Pelée rocks. We extend these data set and propose here a deeper analysis of the hydraulic and electrical properties of these rocks.

[7] In this paper we report laboratory measurements of connected and unconnected porosity, mass density, hydraulic properties (air permeability, distribution of pore access radii and specific surface area) and electrical properties (formation factor, surface conductivity) of 48 volcanic rock samples, mainly pyroclastic rocks, representative of the volcanic deposits of Montagne Pelée. In addition, we paid a special attention to interrelationships between porosity, permeability and formation factor and examine how the pore space characteristics condition the transport properties of pyroclastic rocks.

\section{Geological Context}

[8] Montagne Pelée is one of the most active explosive volcanoes of the Lesser Antilles arc, mainly composed of andesitic pyroclastic materials (around 90\% according to Gunn et al. [1974]). During the last 5000 years, it experienced more than 20 magmatic eruptions. The last ones occurred in 1902-1905 [Lacroix, 1904] and in 19291932 [Perret, 1935] and are dome-forming eruptions. The geology, the stratigraphy of the deposits and the evolutionary stages of this volcano were studied during the last decades [Roobol and Smith, 1976; Westercamp, 1976; Westercamp and Traineau, 1983; Boudon and Lajoie, 1989; Bourdier et al., 1989; Traineau et al., 1989; Vincent et al., 1989; Zlotnicki et al., 1998]. More recently, a new evolution scenario of the volcano based on a succession of constructive growth periods and destructive flank collapse events was proposed [Le Friant et al., 2003; Boudon et al., 2005]. The volcano history is still divided into three main stages. The first stage began its edification probably be- tween 0.5 and $0.3 \mathrm{Ma}$ and saw the construction of the primitive volcano: a cone probably comparable in size with the present edifice. This stage ended $\sim 100,000$ years ago by the flank collapse of the western flank of the volcano generating a debris avalanche, $25 \mathrm{~km}^{3}$ in volume, flowing into the Caribbean Sea and a horseshoe-shaped structure, $8 \times$ $6 \mathrm{~km}$ in size (Le Prêcheur structure). The second stage built a new cone inside the horseshoe-shaped structure. It consists mostly of volcanoclastic breccias (indurated block-and-ash flow deposits) and, subordinate lava domes and lava flows. These breccias mainly outcrop on the western and southern flanks of the volcano. The second stage ended with a second flank collapse event, 25,000 years old that produced a new debris avalanche $\left(13 \mathrm{~km}^{3}\right)$ in the Caribbean Sea and a new horseshoe-shaped structure, $6 \times 4.5 \mathrm{~km}$ in size. The third stage began by the emission of open vent eruptions giving rise to ash-and-scoria flows (named "St. Vincent nuées ardentes") generated from more basic magmas (basaltic andesites). This type of activity occurred during several thousand years and was followed during the last 15000 years by the emission of more acid magma (acid andesites to dacites). Two types of eruptive styles occurred since 15,000 years: Plinian eruptions generating ash-and-pumice fall and flow deposits, and dome-forming events which built lava domes in the summit area and generated block-and-ash flows by collapse of unstable part of the lava dome, and in more rare cases, pyroclastic surges, named Peléean "nuées ardentes," by superficial lateral explosions.

[9] Previous studies show that the chemical composition of Montagne Pelée products remains relatively constant [Gunn et al., 1974; Westercamp, 1976; Bourdier et al., 1985; Fichaut et al., 1989; Gourgaud et al., 1989; Vincent et al., 1989; Villemant et al., 1996; Martel et al., 1998, 2000a, 2000b; Pichavant et al., 2002]. Their bulk composition is generally acid andesitic $\left(59-60 \% \mathrm{SiO}_{2}\right)$. Nonetheless ash-and-scoria flows are derived from quite more basic magmas. Lava flow and lava dome samples are more crystallized that the pyroclastic rocks.

\section{Samples and Measurements \\ 3.1. Samples}

[10] For this study, 48 samples have been chosen, in order to cover the main lithologies and textures of Montagne Pelée volcano (Figure 1). The samples are mainly pyroclastic rocks: pumices from ash-and-pumice fall and flow deposits, poorly vesiculated to nonvesiculated lava blocks from block-and-ash flow and Peléean nuée ardente deposits and scoriae from scoria flow deposits. We also sampled some scarce lava flows and indurated block-and-ash flow deposits from the second stage of evolution (see description in Table 1). Two samples are representative of consolidated ashes found in pyroclastic flows from the second stage. The selected samples are from outcrops (surface sampling) and, even if they are not literally recent rocks, no significant marks of weathering or hydrothermal alteration were observed. Therefore we suppose that the topology of the connected pore space has not changed through an alteration of the rock matrix. Polished thin section observations using light and scanning electron microscopy (SEM) as well as the low electrical surface conduction measured in the samples (see section 4.5) are consistent with this hypothesis. 


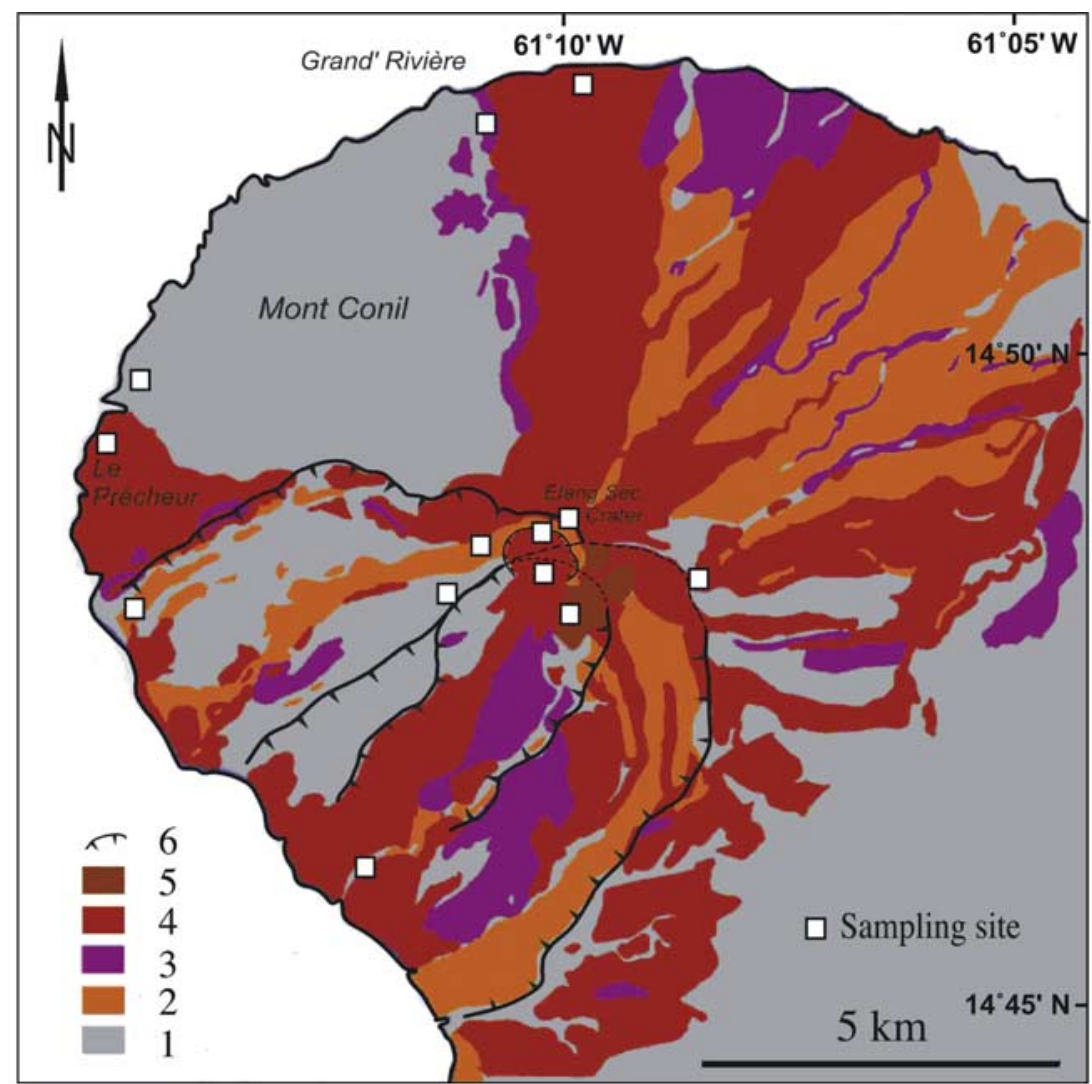

Figure 1. Geological map of the Montagne Pelée (Martinique, Lesser Antilles) from Boudon et al. [2005] and sampling sites: 1, substratum and primitive edifice (stage 1); 2, pumiceous deposits (ash-andpumice fall and flows); 3, scoria flow deposits (stage 3); 4, block-and-ash flow deposits including the 1902-1905 and 1929-1932 eruptions (stages 2 and 3); 5, recent lava domes of the summit area (stage 3); and 6 , horseshoe-shaped structures and summit crater.

[11] Several cylindrical cores were drilled from the parallelepiped sample, previously used for $\mathrm{P}$ and $\mathrm{S}$ wave velocities and attenuation measurements [Bernard, 1999; M. L. Bernard et al., manuscript in preparation, 2007]. In order to estimate the permeability and formation factor anisotropies, two identical cylinders were extracted in two perpendicular directions, in the biggest parallelepiped samples ( 9 and 7 samples, respectively). Two additional cylin- ders have also been extracted from a limited number of samples to measure the pore access radii (18 samples) and the specific surface area (13 samples).

[12] The connected pore space of sample cuts has been resin impregnated, and thin sections have been prepared and observed using optical microscopy. Figure 2 shows thin section and SEM images corresponding to the two main types of samples: a lava block from a block-and-ash flow

Table 1. Description of Montagne Pelée Clasts and Sample Designations Used in This Study

\begin{tabular}{|c|c|c|c|c|c|}
\hline Stage & Eruption & Deposit & Designation & Description & Location \\
\hline $\begin{array}{l}\text { First stage } \\
\text { (substratum) }\end{array}$ & & $\begin{array}{l}\text { indurated block-and-ash } \\
\text { flows }\end{array}$ & MB501 & dense lava blocks & Anse Couleuve \\
\hline \multirow[t]{2}{*}{ Second stage } & & $\begin{array}{l}\text { indurated block-and-ash } \\
\text { flows }\left(\mathrm{TC}^{\mathrm{a}} \text { and } \mathrm{M}^{\mathrm{b}}\right)\end{array}$ & $\begin{array}{l}\text { MA701 and } \\
\text { MI101 }\end{array}$ & $\begin{array}{l}\text { vesicular lava blocks and } \\
\text { indurated ashes }\end{array}$ & Anse Belleville \\
\hline & & lavas and lava domes & LPP & dense lava flows & Montage Pelée \\
\hline \multirow[t]{8}{*}{ Third stage } & - & scoria flows & MF201 & scoriaceous blocks & Grand'Rivière \\
\hline & P1 & ash-and-pumice flows & PP1 & pumices & Morne Lenard \\
\hline & & $\mathrm{NAP}^{\mathrm{d}}$ flows & NP1 & vesicular lava blocks & Rivière Blanche \\
\hline & 1902 & NAP $^{\mathrm{d}}$ flows & PH1 & pumices & Rivière Sèche \\
\hline & & NAP $^{\mathrm{d}}$ flows & NH1 & vesicular lava blocks & Rivière Sèche \\
\hline & & lava dome & DH1-1902 & lava block & Montage Pelée summit \\
\hline & 1929 & block-and-ash flows & NH2 & vesicular lava blocks & Rivière Blanche \\
\hline & & lava dome & DH2-1929 & lava block & Montagne Pelée summi \\
\hline
\end{tabular}

\footnotetext{
aTC "Tombeau des Caraïbes" breccias.

${ }^{\mathrm{b}} \mathrm{M}$ "Macouba" breccias.

${ }^{\mathrm{c}}$ Samples with the notation (m) are indurated ashes.

dNAP Peléean "nuées ardentes."
} 


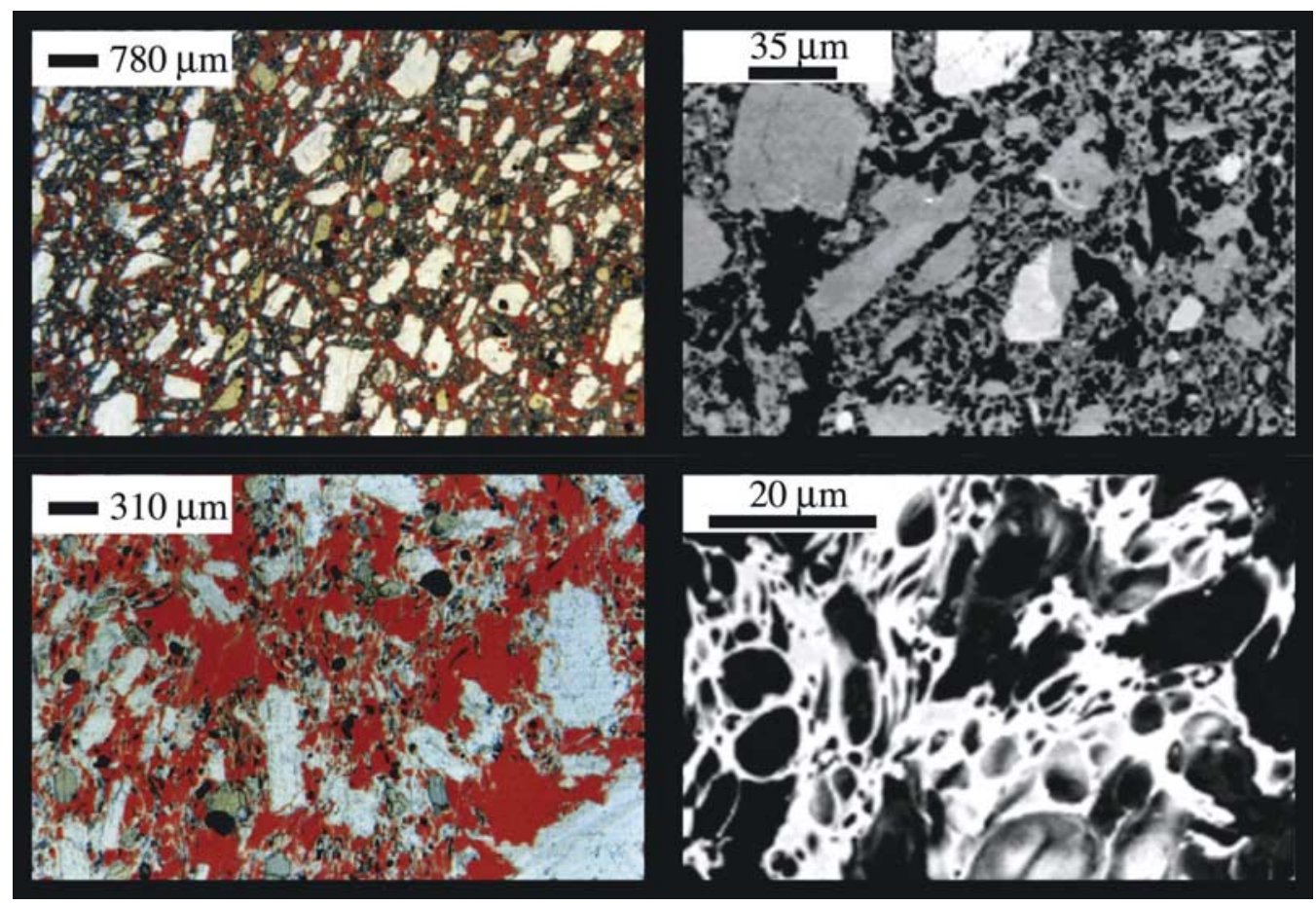

Figure 2. Thin section images from optical and scanning electron microscopy (SEM) of the two main categories of Montagne Pelée pyroclastic products: (top) a lava block and (bottom) a pumice. The pore space is colored in red. The lava block is heterogeneously vesiculated, and vesicle shapes are extremely irregular. The pumice is homogenously vesiculated with near-spherical vesicle shapes.

deposit and a pumice from an ash-and-pumice flow deposit. Large pores connected by small channels seem to characterize the pumices whereas the vesicularity of lava bock presents more variable features. Martel et al. [2000a, $2000 \mathrm{~b}$ ] studied the vesicularity of the recent products from the last eruptions of Montagne Pelée (650 y. B.P (P1), 1902 and 1929 eruptions) using SEM images. In short, they show that (1) the range of porosity in P1 pumices is relatively narrow $(52-68 \%)$ and the pore sizes are generally smaller than $50 \mu \mathrm{m}$ even if some pore sizes can reach more than $500 \mu \mathrm{m}$ due to extensive bubble coalescence; (2) the larger bubbles are elongated, but the pore shape is mainly round; and (3) the porosity of lava blocks is smaller than those of pumices, but their pore size covers a large spectrum.

\subsection{Porosity and Mass Density Measurements}

[13] The connected porosity, $\phi_{c}$, and the apparent mass density, $\rho$, were measured with the triple weighting method, saturating the sample with distilled and degassed water, under vacuum. The samples are cylinders of $2.3 \mathrm{~cm}$ in diameter and $3 \mathrm{~cm}$ in length. The mass density of the solid phase (i.e., rock without pores or matrix), $\rho_{m}$, was measured with a pycnometer on $2-3 \mathrm{~g}$ of rock reduced on fine powder $(10 \mu \mathrm{m})$. The unconnected porosity, $\phi_{t}$, part of the porosity not connected to the exterior, can be calculated knowing the connected porosity and the apparent and matrix mass densities,

$$
\phi_{t}=1-\frac{\rho}{\rho_{m}}-\phi_{c}
$$

[14] The experimental uncertainty on the measures of connected porosity is less than $0.5 \%$ whereas the error on unconnected porosity is less than $1 \%$. The mass densities are obtained with an accuracy of 0.02 to $0.01 \mathrm{~g} \mathrm{~cm}^{-3}$. Porosity measures the pore volume and therefore is not sufficient to characterize the transport properties in natural porous media, which generally depend on pore space geometry.

\subsection{Permeability Measurements}

[15] The air permeability, $k$, was measured at atmospheric pressure with a falling head permeameter [e.g., Bourbié and Zinszner, 1985]. This method is fast and the accuracy is within $1 \%$ for permeability larger than $10^{-15} \mathrm{~m}^{2}$. The measurements have been repeated several times in order to obtain reliable values. The Klinkenberg effect is smaller than $10 \%$ and only affects the less permeable samples $(k<5 \times$ $10^{-15} \mathrm{~m}^{2}$ ). The samples are the cores previously used for measuring the porosities and apparent mass densities.

[16] In order to estimate the permeability anisotropy, these measurements have been performed on two mutually perpendicular cores extracted from the biggest initial blocks. The axis orientation of these samples corresponds to the directions of the minimal and maximal $\mathrm{P}$ wave velocities [Bernard, 1999; M. L. Bernard et al., manuscript in preparation, 2007]. The permeability anisotropy, called $\mathrm{A}_{\mathrm{k}}$, is defined by: $A_{k}=100\left|k_{1}-k_{2}\right| / k_{\text {mean }}$ where $\mathrm{k}_{1}, \mathrm{k}_{2}$ are the permeabilities measured in the two directions, and $\mathrm{k}_{\text {mean }}$ is their average.

\subsection{Distribution of Pore Access Radii and Specific Surface Area}

[17] Two cylinders with diameters of 1 and $2 \mathrm{~cm}$, respectively, and a length of $2 \mathrm{~cm}$ are used to measure the distribution 
of pore access radii (18 samples) and the specific surface area (13 samples). The pore access radii were measured by $\mathrm{Hg}$ injection technique [Géraud, 1991]. The pressure range used during the measurements is $2 \times 10^{-3}$ to $150 \mathrm{MPa}$ which corresponds to a range of measurable pore access radii between 350 and $0.0025 \mu \mathrm{m}$. Therefore, if the sample contains pore access higher than $350 \mu \mathrm{m}$ the mercury will spontaneously invade them and it will be impossible to estimate their proportion.

[18] The specific surface area, $S_{B E T}$, was measured using the Brunauer-Emmett-Teller (BET) nitrogen absorption technique [Dullien, 1992] with a Sorptomatic 1900 (Carlo Erba). In this method, the measured pore surface area corresponds to the entire pore volume connected to the exterior and then included the "dead end" pore walls. The uncertainty is within $2 \%$ for pore surface areas greater than $0.1 \mathrm{~m}^{2} \mathrm{~g}^{-1}$, which is the case here. The pore surface area per pore volume unit, $S_{\text {pore }}=S_{B E T} \rho_{m}(1-\phi) / \phi$, is deduced from these measurements.

\subsection{Electrical Conductivity Measurements}

[19] The electrical formation factors, $F$, and the surface conductivities, $\sigma_{\mathrm{s}}$, of the samples were determined by measuring electrical conductivity of core samples, $\sigma_{\mathrm{r}}$, saturated successively with ten different $\mathrm{NaCl}$ solutions at room conditions. Formation factor describes the effect of the geometry of the porous medium on the macroscopic electrical flow. The cores are those previously used for porosity and permeability measurements.

[20] The experimental protocol and the data inversion procedure are as follows:

[21] 1. The cores were first saturated with distilled water, and subsequently with nine different $\mathrm{NaCl}$ solutions which electrical conductivity increases from $1.6 \times 10^{-3}$ to $17 \mathrm{~S} \mathrm{~m}^{-1}$. The electrical conductivity measurements were performed with a two-pole electrodes technique, at frequencies ranging from $100 \mathrm{~Hz}$ to $100 \mathrm{kHz}$. During measurements, the sample is placed between two stainless steel electrodes connected to an impedance meter (HP4263A). Two paper filters, soaked with the saturating solution, were put between the electrodes and the sample to get good electrical contacts and to prevent polarization effects. A clamping system held the sample between the electrodes with the same constant force for each sample. The electrolyte conductivity was measured with a conductivity cell (Knick 702). The experimental uncertainty is smaller than $1 \%$ and $0.5 \%$ for rock and fluid conductivities, respectively.

[22] 2. Saturation is obtained placing the dried sample in a container under vacuum, before saturating it by filling the container with the electrolyte solutions. The measurements were performed at least 48 hours after the saturation, in order to obtain equilibrated conditions between the rock minerals and the pore fluid. The samples were inserted inside a rubber jacket, to prevent water evaporation and electrolyte conduction on the sample external surfaces. Between two measurements, with two different solutions, the samples were carefully cleaned, by saturating them several times with demineralized water.

[23] 3. The electrical formation factor $F$ and the surface conductivity $\sigma_{s}$ of each sample were determined by nonlinear inversion of the experimental data, $\sigma_{\mathrm{r}}$ and $\sigma_{\mathrm{f}}$, the electrical conductivities of the rock and the electrolyte, respectively, using the Revil and Glover [1998] model

$$
\sigma_{r}=\frac{\sigma_{f}}{F} H\left(\xi, F, t_{+}^{f}\right)
$$

where

$$
H\left(\xi, F, t_{+}^{f}\right)=1-t_{+}^{f}+F \xi+\frac{1}{2}\left(t_{+}^{f}-\xi\right)\left(1-\frac{\xi}{t_{+}^{f}}+\sqrt{\left(1-\frac{\xi}{t_{+}^{f}}\right)^{2}+\frac{4 F \xi}{t_{+}^{f}}}\right)
$$

[24] Here $\mathrm{t}_{+}^{\mathrm{f}}$ is the Hittorf number and represents the fraction of electrical current transported by the cation in the electrolyte. Since we used $\mathrm{NaCl}$ solutions, $\mathrm{t}_{+}^{\mathrm{f}}$ is equal to 0.38 [see Revil et al., 1998]; $\xi$ is a dimensionless parameter defined by Kan and Sen [1987]:

$$
\xi=\frac{\sigma_{s}}{\sigma_{f}}=\frac{2}{3}\left(\frac{\phi}{1-\phi}\right) \frac{\beta_{s} Q_{v}}{\sigma_{f}}
$$

$\beta_{s}$ is the surface mobility of the counterions; $Q_{v}$ is the excess surface charges per unit of pore volume estimated from cation exchange capacity (CEC) measurements [Waxman and Smits, 1968].

[25] In brine-saturated rocks, the electrical conduction inside the grains can be neglected and there are two main electrical conduction mechanisms. The first one is the electromigration of the electrolyte counterions into the connected pore space (bulk conduction), and the second one is due to migration of the weakly absorbed counterions at the pore water-mineral interface (surface conduction). Revil and Glover [1998] assume that the surface conductivity is due to positive counterions only. Consequently, anions migrate only through the connected pore space, while the situation is more complex for cations. At high pore water salinities the electrical conduction contribution of cations is mainly through electromigration in the connected pore space while at low salinities, surface migration is the dominant mechanism [Revil et al., 2002].

[26] Matrix conduction of interfacial origin is almost independent of the electrolyte salinity. This results in a nonlinear dependence of the rock bulk conductivity $\sigma_{\mathrm{r}}$ on the pore fluid conductivity $\sigma_{f}$ at low salinity.

[27] The Revil and Glover [1998] model describes the electrical properties of the porous rock in all the range of salinity of the fluid, which is not the case of the previous models currently used [Waxman and Smits, 1968; Clavier et al., 1977; Johnson et al., 1986, 1987; Johnson and Sen, 1988; Schwartz et al., 1989; Johnson and Schwartz, 1989].

[28] The inversion scheme is based on the Bayesian approach proposed by Tarantola [1987]. We searched the couple $(F, \xi)$ that maximizes the probability density function,

$$
P(F, \xi)=C \exp \left[-\frac{1}{2} \frac{\sum\left(O_{i}-C_{i}\right)^{2}}{S^{2}}\right]
$$

where $C$ is a normalization constant; $O_{i}$ and $C_{i}$ are the observed and theoretical electrical conductivities, respectively. $S$ is a standard deviation, which measures the uncertainty on the conductivity measurements $\left(\sim 0.01 \mathrm{mS} \mathrm{m}^{-1}\right)$. 
Table 2. Measured Mass Density $\left(\rho_{\mathrm{m}}\right)$, Connected and Unconnected Porosity $\left(\phi_{\mathrm{c}}\right.$ and $\left.\phi_{\mathrm{t}}\right)$, and Transport Properties of Pyroclastic Rocks From Montage Pelée Volcano ${ }^{\mathrm{a}}$

\begin{tabular}{|c|c|c|c|c|c|c|c|c|c|}
\hline Sample & $\rho_{\mathrm{m}}, \mathrm{g} \mathrm{cm}^{-3}$ & $\phi_{\mathrm{c}}$ & $\phi_{\mathrm{t}}$ & $\mathrm{k}, 10^{-12} \mathrm{~m}^{2}$ & $\mathrm{~A}_{\mathrm{K}}, \%$ & $\mathrm{~S}_{\mathrm{BET}}, \mathrm{m}^{2} \mathrm{~g}^{-1}$ & $\mathrm{~F}$ & $\mathrm{~A}_{\mathrm{F}}, \%$ & $\sigma_{\mathrm{s}}, \mathrm{mS} \mathrm{m}^{-1}$ \\
\hline \multicolumn{10}{|c|}{ First Stage } \\
\hline MB501-1 z & 2.74 & 0.102 & 0.013 & 0.0010 & & 1.22 & 133 & & 7.2 \\
\hline MB501-2 z & 2.70 & 0.038 & 0.003 & 0.0001 & & & 1139 & & 7.78 \\
\hline \multicolumn{10}{|c|}{ Second Stage } \\
\hline LPP Calebasse $\mathrm{z}$ & 2.85 & 0.031 & 0.010 & 0.0001 & & & 393 & & 1.18 \\
\hline LPP Plumé x & 2.89 & 0.035 & 0.016 & 0.0001 & & 0.86 & 273 & & 1.60 \\
\hline LPP Macouba y & 2.76 & 0.134 & 0.001 & 0.0010 & & & 53 & & 0.78 \\
\hline MA701-1 y & 2.76 & 0.240 & 0.001 & 0.2536 & & 0.74 & 18 & & 0.26 \\
\hline MA701-2 y & 2.77 & 0.145 & 0.007 & 0.0049 & & & 49 & & 0.34 \\
\hline MA701-3 z & 2.71 & 0.289 & 0.023 & 5.0570 & & & 19 & & 0.29 \\
\hline MI101-1 x & 2.72 & 0.111 & 0.007 & 0.0039 & 28 & & 136 & 0 & 0.26 \\
\hline MI101-1 z & 2.72 & 0.103 & 0.009 & 0.0030 & & & 137 & & 0.34 \\
\hline MI101-2 z & 2.71 & 0.132 & 0.001 & 0.0089 & & 0.46 & 55 & & 0.29 \\
\hline MI101-4 x & 2.72 & 0.149 & 0.007 & 0.0553 & & & 44 & & 0.21 \\
\hline MI101-5 z & 2.69 & 0.146 & 0.008 & 0.0030 & & & 55 & & 1.77 \\
\hline MA701-m x & 2.68 & 0.305 & 0.006 & 1.7735 & & & 13 & & 0.47 \\
\hline MI101-m x & 2.63 & 0.321 & 0.004 & 0.5695 & & & 14 & & 8.68 \\
\hline \multicolumn{10}{|c|}{ Third Stage } \\
\hline MF201-1 y & 2.86 & 0.363 & 0.026 & 1.5435 & & & 16 & & 2.67 \\
\hline MF201-2 x & 2.81 & 0.280 & 0.016 & 1.0294 & & 1.03 & 25 & & 0.50 \\
\hline MF201-3 y & 2.84 & 0.352 & 0.029 & 5.6896 & & 2.09 & 9 & & 11.80 \\
\hline NP1-A z & 2.67 & 0.099 & - & 0.0188 & - & & - & & - \\
\hline NP1-F1 x & 2.67 & 0.169 & 0.033 & 0.0059 & 40 & & 195 & 13 & 0.63 \\
\hline NP1-F1 y & 2.67 & 0.157 & 0.023 & 0.0039 & & & 222 & & 0.65 \\
\hline NP1-F2 x & 2.67 & 0.174 & 0.018 & 0.1086 & 162 & $<0.1$ & 97 & 34 & 1.64 \\
\hline NP1-F2 z & 2.67 & 0.190 & 0.031 & 0.0109 & & & 136 & & 0.71 \\
\hline NP1-F3 y & 2.69 & 0.158 & - & 0.0385 & 136 & & 77 & 16 & 0.00 \\
\hline NP1-F3 z & 2.69 & 0.146 & 0.017 & 0.2043 & & & 65 & & 0.73 \\
\hline NP1-C y & & 0.312 & - & 0.0592 & & & - & & - \\
\hline NP1-B x & 2.67 & 0.415 & 0.052 & 0.6701 & 73 & & 17 & & 3.6 \\
\hline NP1-B y & 2.67 & 0.428 & - & 1.4488 & - & & - & & - \\
\hline NH1-I & 2.69 & 0.119 & 0.005 & 0.0029 & & & 101 & & 0.03 \\
\hline NH1-N & 2.70 & 0.197 & 0.002 & 0.1668 & & & 25 & & 0.00 \\
\hline NH1-K & 2.69 & 0.251 & 0.023 & 1.5830 & & $<0.1$ & 17 & & 0.11 \\
\hline NH1-L & 2.68 & 0.274 & 0.020 & 2.9124 & & & 14 & & 0.17 \\
\hline NH1-O & 2.70 & 0.304 & 0.022 & 1.1843 & & & 10 & & 18.9 \\
\hline NH2-S & 2.78 & 0.099 & 0.001 & 0.0010 & & & 86 & & 1.17 \\
\hline NH2-P x & 2.62 & 0.213 & 0.000 & 0.2270 & 84 & & 51 & 36 & 0.97 \\
\hline NH2-P y & 2.62 & 0.232 & 0.005 & 0.5537 & & & 36 & & 1.59 \\
\hline NH2-R & 2.71 & 0.328 & 0.031 & 10.2068 & & & 9 & & 1.35 \\
\hline NH2-Q x & 2.67 & 0.408 & 0.020 & 34.4298 & 33 & $<0.1$ & 10 & 6 & 11.7 \\
\hline NH2-Q z & 2.67 & 0.353 & 0.055 & 33.3235 & & & 9 & & 3.10 \\
\hline D-Aileron & 2.74 & 0.154 & 0.020 & 0.0039 & & & 48 & & 0.83 \\
\hline DH1-1902 & 2.72 & 0.098 & 0.007 & 0.0020 & & & 66 & & 0.10 \\
\hline DH2-1929 & 2.74 & 0.121 & 0.001 & 0.0039 & & 0.14 & 66 & & 0.26 \\
\hline PP1-D3 & 2.63 & 0.547 & 0.110 & 0.2073 & & & 29 & & 8.72 \\
\hline PP1-M y & 2.65 & 0.536 & 0.150 & 0.4254 & 99 & & 35 & 6 & 6.30 \\
\hline PP1-M z & 2.65 & 0.574 & 0.100 & 0.1441 & & & 38 & & 0.30 \\
\hline PP1-H x & 2.67 & 0.574 & 0.092 & 1.1813 & 54 & & - & & - \\
\hline PP1-H & 2.67 & 0.578 & 0.086 & 2.0538 & & & 15 & & 6.53 \\
\hline PP1-E y & 2.67 & 0.585 & 0.097 & - & & & 36 & & 9.65 \\
\hline PP1-G X & 2.65 & 0.617 & 0.080 & 7.6605 & & & 7 & & 2.22 \\
\hline
\end{tabular}

${ }^{a}$ Transport properties are air permeability $(\mathrm{k})$, electrical formation factor $(\mathrm{F})$, electrical surface conductivity $\left(\sigma_{\mathrm{s}}\right)$, and $\mathrm{S}_{\mathrm{BET}}$ is the specific surface area. $\mathrm{A}_{\mathrm{k}}$ and $A_{F}$ are designed permeability and formation factor anisotropies, respectively.

[29] Like the permeability anisotropy (section 3.3), we estimate the formation factor anisotropy, $A_{F}=100\left|F_{1}-F_{2}\right| /$ $F_{\text {mean }}$ where $F_{1}, F_{2}$ are the formation factor measured in two perpendicular directions, and $F_{\text {mean }}$ is their average.

\section{Results}

[30] Table 2 presents the matrix mass density, the connected and unconnected porosities, the air permeability, the permeability anisotropy, the BET specific surface area, the formation factor, the formation factor anisotropy, and the surface conductivity.

\subsection{Porosity and Mass Density}

[31] Figure 3 shows the unconnected porosity, $\phi_{t}$, as a function of the connected porosity, $\phi_{c}$. While $\phi_{c}$ varies over a wide range, from $3 \%$ in the lavas to $62 \%$ in the pumices, $\phi_{t}$ is generally smaller than $3 \%$, except in the pumices where it can reach $15 \%$. 


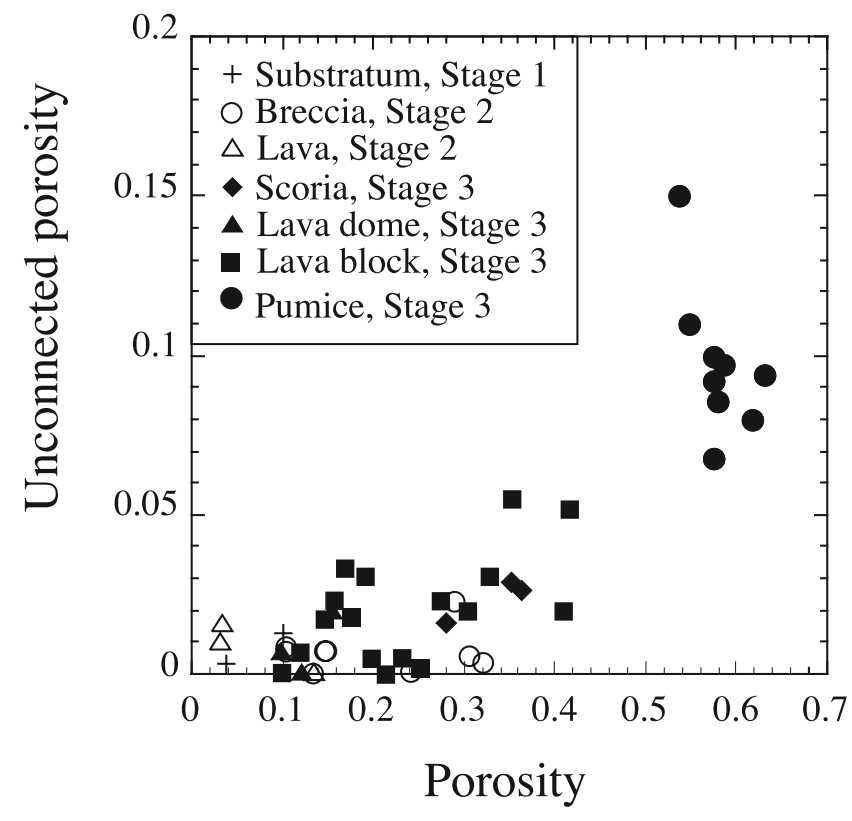

Figure 3. Unconnected porosity as a function of connected porosity. The different symbols correspond to the different deposits studied (see Table 1 for more details).

[32] The solid mass densities, $\rho_{m}$, are relatively constant, particularly in pumice and lava block samples from the third stage (Table 2). This is in agreement with the chemical and mineralogical composition of the Montagne Pelée products (see section 2). The average mass density is close to $2.7 \mathrm{~g} \mathrm{~cm}^{-3}$ in most of the samples. Higher values (2.8 to 2.9) are observed in the samples of scoria and lava flow. The scorias are derived from more basaltic magma whereas the lava flow samples are more crystallized: that explains their higher solid mass density. Consequently, the studied samples have a similar rock matrix but quite different pore microstructure.

\subsection{Permeability}

[33] The permeability covers more than 5 orders of magnitude, from $10^{-16}$ to $35 \times 10^{-12} \mathrm{~m}^{2}$ (Table 2). The higher permeability values (up to $35 \times 10^{-12} \mathrm{~m}^{2}$ ), comparable to those measured on clean sands, were obtained in some blocks from block-and-ash flow and scoria flow deposits in spite of the fact that these rocks are less porous than the pumices. The lower values $\left(<10^{-15} \mathrm{~m}^{2}\right)$ correspond to lava samples. On pumices, the range of permeability is narrow $(0.15-8 \times$ $10^{-12} \mathrm{~m}^{2}$ ) and comparable to those measured on pumices from other volcanoes [Klug and Cashman, 1996; Tait et al., 1998; Klug et al., 2002; Melnik and Sparks, 2002].

[34] The porosities of the cores extracted from the same rock sample, but in two different directions, are relatively close. This indicates that the core volume is representative of the pore volume of the samples. However, the core permeability can be quite different since the permeability anisotropy, $A_{k}$, is extremely variable, ranging from 28 to $162 \%$. Tait et al. [1998] also observed an important anisotropy of permeability in Minoan pumices $(>50 \%)$.

\subsection{Distribution of the Pore Access Radii and Specific Surface Area}

[35] Figure 4 shows 15 distributions of the pore access radii that cover the different lithologies of the Montagne
Pelée rocks. The normalized cumulative volume of mercury injected (saturation) is also reported. These distributions reflect the diversity in the pore space geometry of the studied samples. On the majority of the samples we observe a wide, bimodal or quasi-monomodal, spectrum of pore access radii, ranging from $2 \times 10^{-3}$ to $10^{2} \mu \mathrm{m}$. The exceptions are the pumices (PP1 and PH1 series), which generally do not have pore access radii smaller than $10^{-1} \mu \mathrm{m}$. At the opposite, in the lava flow (Plumé) and the lava dome (D1929), the pore access radii larger than $5 \mu \mathrm{m}$ are uncommon.

[36] Two families of pore access radii, more or less differentiated, are generally observed in the indurated block-and-ash flow deposits (MI and MA series), the lava blocks (NP1 and NH2 series), the scoria (MF serie) and the pumices, but their relative proportion may be very different. The lava blocks and the scoria have a bimodal distribution of pore access radii and the large pore access radii, ranging from 5 to $100 \mu \mathrm{m}$, generally predominate. On pumices, the distribution of pore access radii is quasi-monomodal and most of the pore access radii are smaller than $10 \mu \mathrm{m}$. The pumice pores are large (high porosity) but connected with narrow apertures ("ink bottle" pores) [Whitham and Sparks, 1986]. This difference in the pore access radius distributions explains why the permeability in the lava blocks and scorias can be more important than in the pumices, even if their porosities are smaller. See, for example, the lava block NH2-Q, the scoria MF-3 and the pumice PP1-D3 in Figure 4. The high permeabilities $\left(>5 \times 10^{-12} \mathrm{~m}^{2}\right)$ are associated to the samples having large pore access radii $(>10 \mu \mathrm{m})$ or large pore size (high porosity) connected by relatively large throats (see PP1-G).

[37] Polymodal distributions of pore size or pore access radius in volcanic rocks have been attributed to multiple stages of bubble nucleation and growth [Sparks and Brazier, 1982; Whitham and Sparks, 1986] and to bubble coalescence [Klug and Cashman, 1996; Mangan and Cashman, 1996].

[38] The specific surface areas, $\mathrm{S}_{\mathrm{BET}}$, are relatively small, ranging from 0.1 to $2.1 \mathrm{~m}^{2} \mathrm{~g}^{-1}$, except for three lava blocks and two pumices, where they are under the resolution limit of the apparatus, $0.1 \mathrm{~m}^{2} \mathrm{~g}^{-1}$. In general, high specific surface area are associated with low hydraulic pore radius, $\mathrm{R}_{\mathrm{h}}$, and therefore low permeability. In Montagne Pelée rocks, the larger values are observed in samples from lava flows and lava domes with low permeability, as expected, but also in scoria with large permeability. The mean hydraulic pore radius, $\mathrm{R}_{\mathrm{h}}$, computed using the specific surface area per pore volume unit, $\mathrm{S}_{\text {pore }}$, and the relationship for tubular medium [Schopper, 1982], $R_{h}=2 / S_{\text {pore }}$, ranges from 0.02 to $5.4 \mu \mathrm{m}$.

\subsection{Formation Factor, Surface Conductivity, and Electrical Tortuosity}

[39] In the Table 2 we report the formation factors, $F$, and the surface conductivities, $\sigma_{s}$, determined from the electrical conductivities measured at $100 \mathrm{kHz}$, using the Revil and Glover model (noted RG). We choose the data at $100 \mathrm{kHz}$ since they correspond to the minimal phase difference in all samples. Figure 5 shows an example of rock electrical conductivity, $\sigma_{r}$, versus pore fluid conductivity, $\sigma_{f}$.

[40] The formation factor, $F$, ranges from 7 to 1139 . The larger values are obtained in lavas and indurated block-andash flow deposits (breccias) whereas the smaller values 


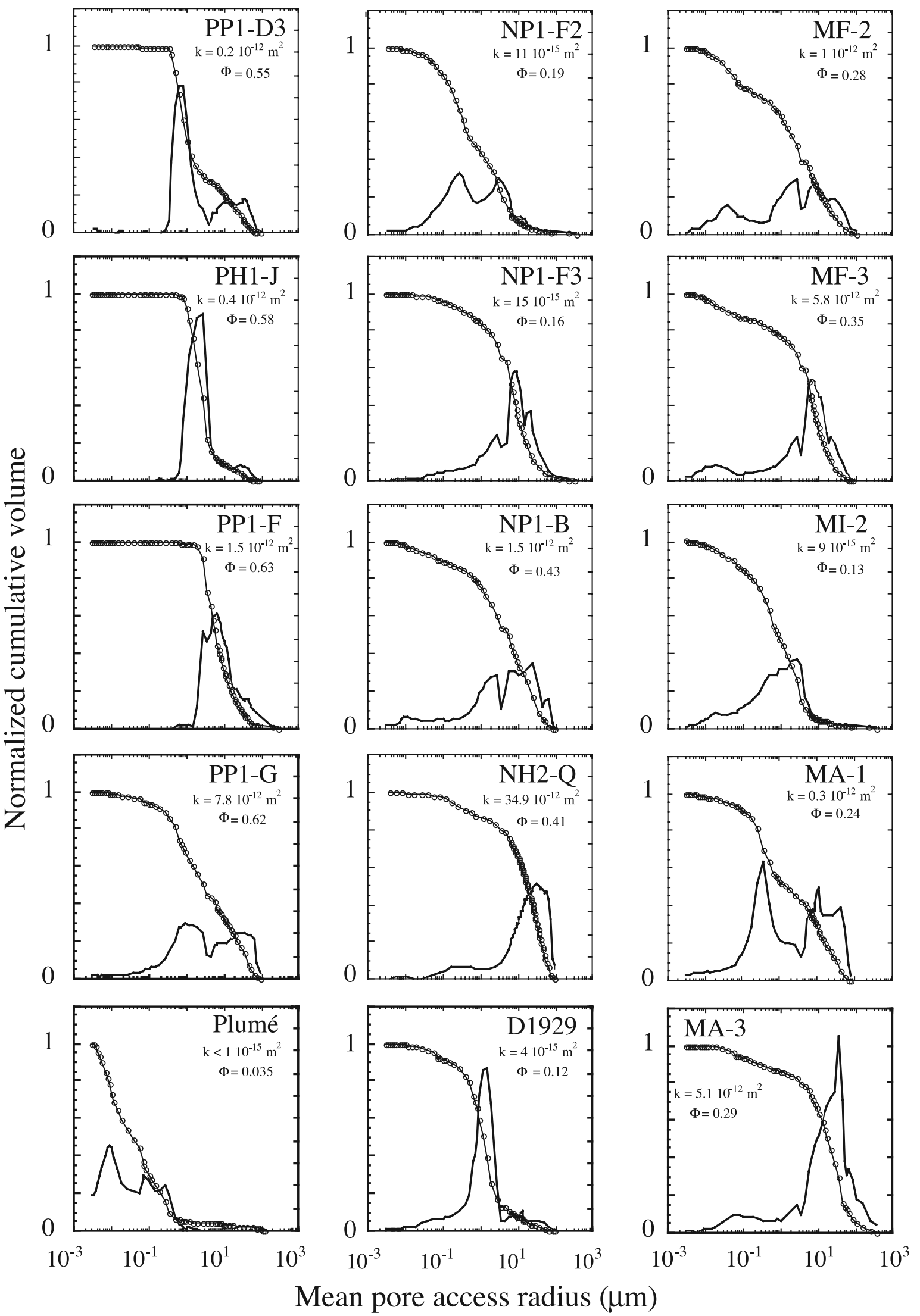

Figure 4. Distributions of pore access radius (solid line) and normalized cumulative volume of mercury injected (solid line with circles) from Hg porosimetry measurements on 15 samples characteristics of Montagne Pelée deposits. The $k$ and $\Phi$ are the permeability and the porosity, respectively, of the samples. See sample designations in Table 1. 




Figure 5. An example of rock conductivity variation as a function of the saturating fluid conductivity in a Montagne Pelée sample. The solid line corresponds to a data fit using the Revil and Glover [1998] model.

$(F<20)$ correspond to highly porous and permeable samples (pumices and scoria). The electrical anisotropy $\mathrm{A}_{\mathrm{F}}$ is smaller than $36 \%$. The effect of rock anisotropy is greater on the permeability. The surface conductivity, $\sigma_{s}$, range from $10^{-5}$ to $19 \times 10^{-3} \mathrm{~S} \mathrm{~m}^{-1}$ and are small compared to surface conductivities measured in rocks with clays, where surface conductivity is generally greater than $10^{-3} \mathrm{~S} \mathrm{~m}^{-1}$ [Waxman and Smits, 1968]. This agrees with the small values of CEC ( 0.01 to $\left.0.05 \mathrm{meq} \mathrm{g}^{-1}\right)$ measured in most of the samples. The larger values of the CEC $\left(0.04\right.$ and $\left.0.05 \mathrm{meq}^{-1}\right)$ are observed on the oldest samples from the substratum (MB501 serie) and may be due to weak weathering. Larger CEC values $\left(>0.05 \mathrm{meq}^{-1}\right)$ are generally associated to clay minerals [Schön, 1996]. These results confirm that weathering effect remains negligible in the selected samples.

[41] An additional parameter characterizing the pore structure can be deduced from porosity and electrical measurements: the electrical tortuosity defined as $\tau_{e}=\sqrt{F \phi_{c}}$ [see Brown, 1980]. Similarly to hydraulic tortuosity that measures the geometry of the fluid flow paths, the electrical tortuosity describes the path geometry associated with electrical current transport in a porous media. Fluid flow tortuosity is systematically larger than the electrical tortuosity and can differ by as much as an order of magnitude at lower porosities [David, 1993]. The constrictions in the pores may have a greater effect on hydraulic resistance to fluid flow that it does on electrical resistance. Results show that electrical tortuosity in pyroclastic rocks cover a large spectrum of values between 1.7 and 6.5. This indicates different degree in the complexity of their pore network.

\section{Discussion}

[42] In this section we discuss the relationship between porosity, permeability and formation factor in the pyroclas- tic rocks. These relations provide a quantitative basis to evaluate the pore microstructure features on which these transport properties depend and therefore the possibility to get information on the pore microstructure through bulk transport properties of pyroclastic rocks. Measurements are compared to predictions of different theoretical models, based on geometrical considerations or percolation theory and depending on microstructural characteristics such as pore dimension and connectivity. We also relate these results to the main hypothesis on magma degassing processes proposed in literature for this volcano. At the end of this section, we introduce field data available in literature on hydrogeological properties of Montagne Pelée deposits and compare them to laboratory measurements but without push the analysis far since it is well know that transport properties depend on scale measurement.

\subsection{Permeability-Porosity Relationship}

[43] Figure 6 shows that the permeability of Montagne Pelée samples increases with the connected porosity but with different trends for different lithologies, like in sedimentary rocks for different grain size distributions. Three behaviors may be observed if we assume that the porosity, $\phi_{c}$, and the permeability, $k$, are connected through a power law like,

$$
k=C \phi_{c}^{n}
$$

where $C$ is a constant:

[44] 1. On the less porous samples $\left(\phi_{c} \leq 10 \%\right)$ from the substratum and lava flow deposits the best fit is obtained for $n \approx 2$, characteristic of crack porosity. The correlation coefficient, $R$ (from least squares curve fit) is equal to 0.95 ;

[45] 2. On pumices, the correlation is weak $(R=0.51)$ and $n$ is very high and unusual $(n \approx 16)$. The permeability varies

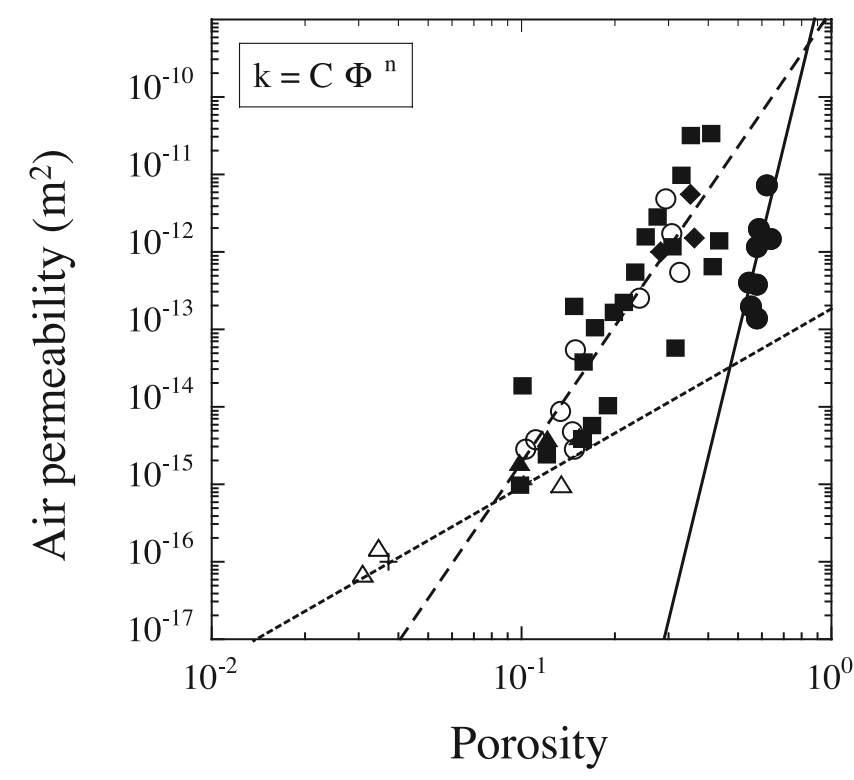

Figure 6. Air permeability as a function of connected porosity. The symbol description is given in Figure 3. The regression lines correspond to the Carman-Kozeny model $k=C \phi^{n}$ for the three main trends observed: $\mathrm{n} \approx 2$ (dotted line), $\mathrm{n} \approx 5$ (dashed line), and $\mathrm{n} \approx 16$ (solid line). See comments in section 5.1 . 
considerably: 2 orders of magnitude for a small $(<10 \%)$ porosity variation;

[46] 3. On all the other rocks, the exponent is also relatively high $(n \approx 5)$ and the correlation coefficient is larger $(R=0.61)$.

[47] 4. Grouping all the data leads to a very low $R(=0.1)$.

[48] The large values of $n$ may indicate that only a limited part of the connected porosity participates to the hydraulic transport, and may be attributed to a percolation threshold phenomenon. Multiple processes in the physical, chemical, biological, and earth sciences appear to show power law (i.e., fractal) properties above a certain threshold and may thus be described by percolation theory.

[49] Various authors have shown the role of percolation in transport properties of porous media (for reviews, see Dullien [1992], Adler [1992], and Sahimi [1994]). In any given rock, there must be a certain minimum threshold porosity $\phi_{p}$ before through going connected paths exist [Kirkpatrick, 1973; Bernabé et al., 1982; Berkowitz and Ewing, 1998]. It is only the porosity in excess of the threshold porosity that determines the permeability [Mavko and Nur, 1998].

[50] Rust and Cashman [2004] study the permeability of crystal-poor obsidian flow and pumice samples to assess the existence of such a critical porosity below which silicic magma is effectively impermeable. They do not observe an abrupt decrease in permeability below $60 \%$ porosity, as found previously by Eichelberger et al. [1986] for Obsidian Dome (USA) samples. However, they do not prelude a percolation threshold at lower porosity, i.e., $\phi_{p}<0.3, \phi_{p}<$ 0.16 and $\phi_{p}<0.023$, for samples from Mont Saint Helens, Montagne Pelée and Soufrière Hills volcanoes, respectively. Similar observations on vesicular basalts (lava and scoria) lead Saar and Manga [1999, 2002] to the conclusion that the percolation threshold $\phi_{p}$ is smaller than 0.3 , the value predicted by percolation theory for overlapping uniform spherical bubbles [Feng et al., 1987; Blower, 2001; Blower et al., 2001, 2002].

[51] Substituting $\phi$ by $\left(\phi_{c}-\phi_{p}\right)$ in equation (4), we obtain

$$
k=C\left(\phi_{c}-\phi_{\mathrm{p}}\right)^{n}
$$

[52] Rocks with different diagenesis history might have different characteristic percolation threshold porosity. Rust and Cashman [2004] suggest that both vesicle microstructure and the resulting porosity-permeability relationship depend on the deformation, decompression and degassing history of the magma. To get the best fit using equation (5), we have to set $\phi_{p}=0.5$ for pumices and $\phi_{p}=0.1$ for the others lithologies, except the substratum and lava flow samples where $\phi_{p}$ is assumed to be zero. Then a unique exponent $n$ close to $3(n \approx 2.7)$ allows to describe the $\mathrm{k}-\phi$ relationship, and improve the correlation coefficient for the entire data set $(R=0.60)$.

[53] An exponent $n$ close to 3 is consistent with the Carman-Kozeny (CK) model [Carman, 1956]. In this model, the pores are idealized as capillary channels. The channel cross sections have complicated shapes but, on the average, a constant area. The CK model links the permeability $k$ to the porosity, $\phi$, the pore channel tortuosity, $\tau_{h}$, and the pore surface area per unit volume of rock, $S_{\text {tot }}$, or the so-called "mean hydraulic radius," $R_{h}$, by

$$
k_{C K}=\frac{\phi R_{h}^{2}}{4 \chi \tau_{h}^{2}}=\frac{\phi^{3}}{\chi \tau_{h}^{2} S_{t o t}^{2}},
$$

$\chi$ is the cross section shape factor, equal to 2 for a circular section. Equation (6) shows the both influence of porosity and pore geometry on permeability, as well as the dominant effect of pore geometry, according to the squared dependence of $k$ on $R_{h}$ and $\tau_{\mathrm{h}}$. The tortuosity is the squared ratio of the mean flow path length to the medium length.

[54] The CK model introduces a direct dependence between porosity and permeability, and, through the concepts of specific surface area and tortuosity, leads to an explanation of how permeability depends on local rock texture. However, the CK model does not take into account other important topology characteristics such as pore connectivity or pore size fluctuation.

[55] In the last decades, new models, based on the use of capillary pressure curves and percolation theory, were developed. These models depend on the pore access radius distributions and then better integrate the effect of pore network topology on transport properties. Among these models, the Katz and Thompson [1986, 1987] model introduces the concept of percolation threshold and connects the permeability with two characteristic lengths of the pore space. The first one, $r_{c}$, is the radius corresponding to the threshold pressure in a mercury injection experiment. It defines the point at which the invading mercury first forms a connected path spanning the rock sample. The second one, $r_{h}$, is the pore access radius that optimizes the hydraulic conductance. This model assumes that only the pores with access radii lower than $r_{c}$ participate to the permeability. Therefore the permeability is given on this model by

$$
k_{K T}=\frac{1}{89} \frac{r_{h}^{2}}{r_{c}} \phi S\left(r_{h}\right),
$$

where $S\left(r_{h}\right)$ is the $\mathrm{Hg}$ saturation of the pore space composed by pores having an access radius $r$, with $0 \leq r \leq r_{c}$. The radii $r_{c}$ and $r_{h}$ are determined from the capillary pressure curves (for details, see Katz and Thompson [1987]). Percolation theory was developed to mathematically deal with disordered media, in which the disorder is defined by a random variation in the degree of connectivity.

[56] Figure 7 compares the measured permeability and the theoretical permeability obtained with the CarmanKozeny (CK) and Katz and Thompson (KT) models. The $\mathrm{CK}$ model underestimates the permeability by up to 4 orders of magnitude. The disagreement between the experimental data and the CK predictions cannot result from a difference between the values of hydraulic and electrical tortuosities, because the difference between these two quantities is smaller than 1 order of magnitude, as David [1993] demonstrates through numerical simulations. The hypothesis that the hydraulic radius obtained by BET measurements is smaller than the mean capillary radius actually participating to the fluid transport can be proposed to explain such disagreement (see section 5.4). Moreover, porous media in 


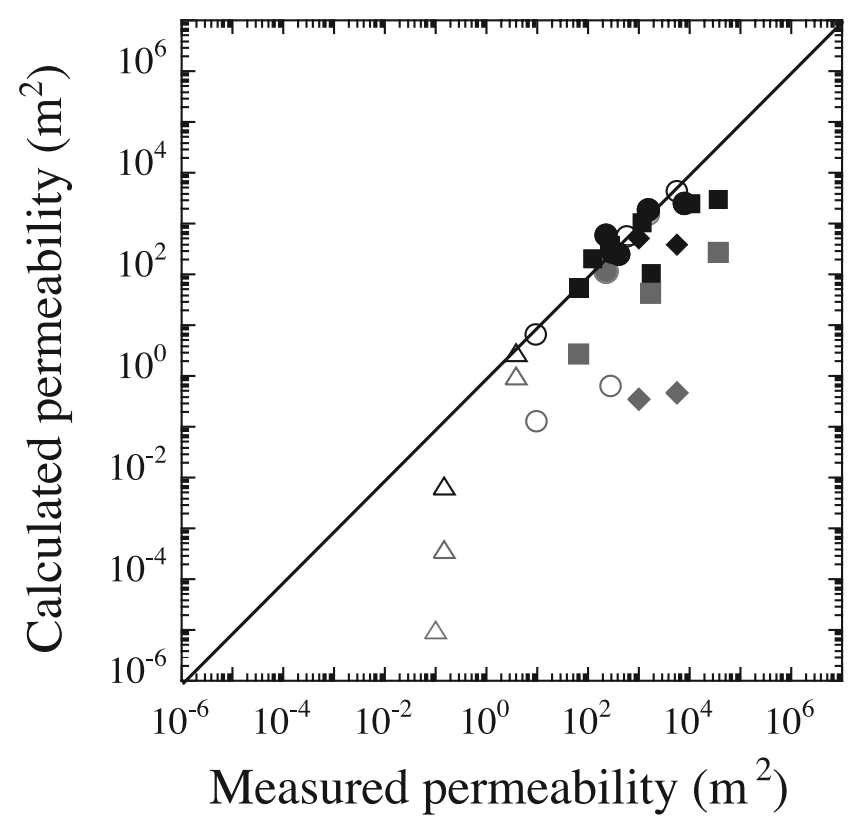

Figure 7. Comparison of measured permeability with the calculated values using the theoretical models of CarmanKozeny [Carman, 1956] (gray symbols) and Katz and Thompson [1986, 1987] (black symbols).

nature are not composed of well-connected constant pore diameter capillaries.

[57] The Katz and Thompson (KT) model gives a better estimation of the permeability than the CK model. Indeed the difference between the measured and calculated permeability using KT model is smaller than 1 order of magnitude, except for five samples. Four of these samples present large pore access radius spectra and the beginning of their $\mathrm{Hg}$ porosimetry curve is not well defined. Consequently, the error on the $r_{c}$ estimated in these samples is larger. The KT model is better adapted to pyroclastic rocks because only the part of pores participating efficiently to the hydraulic transport is taking into account. The two radii $r_{c}$ and $r_{h}$ are generally 1 or 2 orders of magnitude higher than the hydraulic radius deduced from BET measurements (see section 5.4).

\subsection{Formation Factor-Porosity Relationship}

[58] Figure 8 shows the formation factor, $F$, as a function of the connected porosity $\phi_{c}$. The different lines correspond to different values of the cementation factor $m$, a parameter of the well-known Archie empirical law [Archie, 1942],

$$
F=\phi_{c}^{-m}
$$

[59] The parameter $m$ reflects the ratio between the connected porosity and the pore space volume useful for electrical flows. Wong et al. [1984] proposed that m may be larger in porous media with wide fluctuations of pore size. For a majority of the samples, $m$ is between 2 and 3 like in most sedimentary rocks [Schön, 1996]. The lower m (between 1 and 2) is found in lavas and lava domes. Pezard et al. [1990] showed that a value of $m$ close to 1 indicates that the conducting pore space of the rock is mainly compose of cracks and micro cracks. The higher values of $\mathrm{m}(\mathrm{m} \approx 6)$ are observed in the pumices and confirm a strong discrepancy between the connected porosity and the pore volume participating to fluid flows. As we show in section 4.3, the pumice pores are large but their access radii are small. Therefore the pore sections efficient for electrical flows are small and, like the permeability, the formation factor is weakly dependent on connected porosity in pumices.

[60] However, if we use the modified form of equation (8): $F=a \phi_{-m}$, to relate $F$ to $\phi$, for each lithology or grouping all the data, the correlation coefficients obtained are greater than those computed in section 5.1, using equations (4) or (5). As an illustration, grouping all the data except the pumices, we found $R \approx 0.73$ from the above modified form of equation (8) whereas $R \approx 0.61$ from equation (4). This indicates that porosity has a stronger effect on formation factor than permeability, which depends stronger on details of the pore microstructure. The sparse data on permeability and formation factor anisotropy presented in section 4 , is in agreement with a stronger dependence of permeability on the pore space heterogeneities. Keller [1989] studied electrical properties of volcanic rocks (tuff, aa and pahoehoe) for a large range of porosity, 20 to $80 \%$. He used the modified form of Archie law, with $a=3.5$ and $m=1.44$ to relate $F$ and $\phi$ in volcanic rocks. A similar relationship exists for Montagne Pelée data presented in this paper, since $a=2.65$ and $m=1.63$ provide the best fit $(R=0.73)$.

\subsection{Formation Factor-Permeability Relationship}

[61] The textural influence upon $F$ and $k$ is the physical basis used in investigations attempting to find a correlation between these parameters. Figure 9 shows a relatively good correlation between $F$ and $k$ in the pyroclastic rocks, over the entire data set $(R=0.76)$. The pumices not show



Figure 8. Formation factor as a function of porosity. The symbol description is given in Figure 3. The regression curves (solid lines) correspond to the Archie model for different $m$ value. 


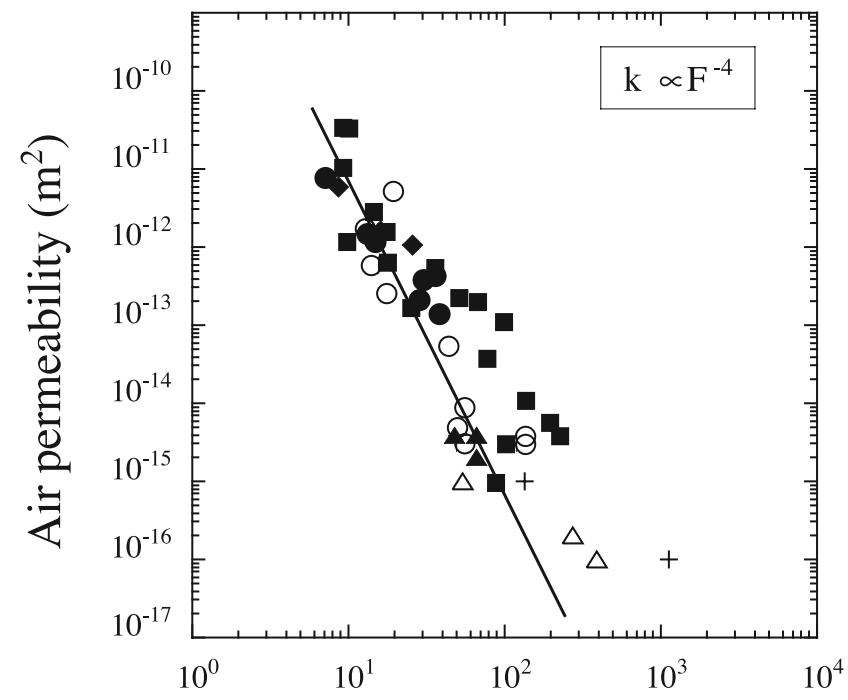

Formation factor

Figure 9. Formation factor as a function of permeability. The symbol description is given in Figure 3. The solid lines correspond to a fitting curve using the Pape et al. [1984] model.

particular behavior which contrast to previous results in sections 5.1 and 5.2.

[62] Figure 10 confirms that strong similarities exist between electrical and hydraulic conduction paths in pyroclastic rocks, particularly in scoria and pumice samples. For each lithology, the electrical tortuosity $\tau_{e}$ correlates with the permeability. The difference between path geometries of the hydraulic and electrical conductions, characterized by $\tau_{h}$ and $\tau_{e}$, respectively, increases with the pore electrical surface conduction $\sigma_{s}$, which is negligible in our samples (see section 4.4), and the heterogeneity of the pore space [David et al., 1990]. According to this last result, the correlation between $\tau_{e}$ and $k$ being stronger in scoria and pumices samples (Figure 10), the pore textures of these rocks may be relatively more homogeneous compared to the other samples.

[63] Modeling the pore networks with a capillary tube model, like in the CK model, leads to $F=\tau_{e}^{2} / \phi$. Therefore, assuming that the pathways for the fluid flow and the electrical current are the same, e.g., $\tau_{h}=\tau_{e}$, the following relationship between the permeability and the formation factor results:

$$
k \propto \frac{1}{S_{\text {pore }}^{2}} F^{-1},
$$

where $S_{\text {pore }}=S_{\text {tot }} / \phi$. We have already unsuccessfully tested this relation in section 5.1 since we used the electrical tortuosity to compute $\mathrm{k}_{\mathrm{CK}}$.

[64] Katz and Thompson [1987] propose a relation to estimate the formation factor to $\mathrm{Hg}$ porosimetry, based on the percolation theory. Then they link the permeability to the $\mathrm{Hg}$ porosimetry and electrical data ( $r_{c}$ and $F$, respectively):

$$
k=\frac{4}{226} r_{c}^{2} F^{-1} .
$$

[65] The permeability is, in general, overestimated by a factor two by applying this relation on the $\mathrm{Hg}$ porosimetry and electrical data presented in this study. This factor may result from the coefficient (4/226) in equation (10) related to the simplistic modeling of the pore network by cylindrical channels, or/and a difference between hydraulic and electrical tortuosity.

[66] The $k-F$ relation is also in agreement with Pape et al.'s [1981, 1982, 1984, 1987, 1999] studies, which predict $k \propto F^{-4}$ using a so-called pigeonhole model to describe the pore geometry of sedimentary rocks. The pigeonhole model is based on fractal theory and opens the possibility of understanding the effect of interface phenomena on hydraulic and electrical properties of rocks. This result is interesting since the processes determining pore structure in volcanic and sedimentary rocks are different. In volcanic rocks, the pore microstructure (shape, size, orientation, connectivity) is determined by processes that promote nucleation, growth or coalescence of gas bubble in magma, such as the decompression of volatile-rich magma in volcanic conduits and it exposure to atmospheric pressure. Sedimentary rocks result from the lithification of sediments, which involves compaction, cementation and recrystallization (of carbonate sediments). Consequently, Pape et al. results may endure some deviation from the pure pigeonhole model.

\subsection{Characteristic Lengths Controlling Transport Properties}

[67] Johnson et al. [1986] defines a characteristic length $\Lambda$ for electrical conduction. This parameter is a dynamic measurement of the pore throat that controls electrical conduction. Assuming similarities between electrical and hydraulic potential fields in the rock, Johnson and Schwartz

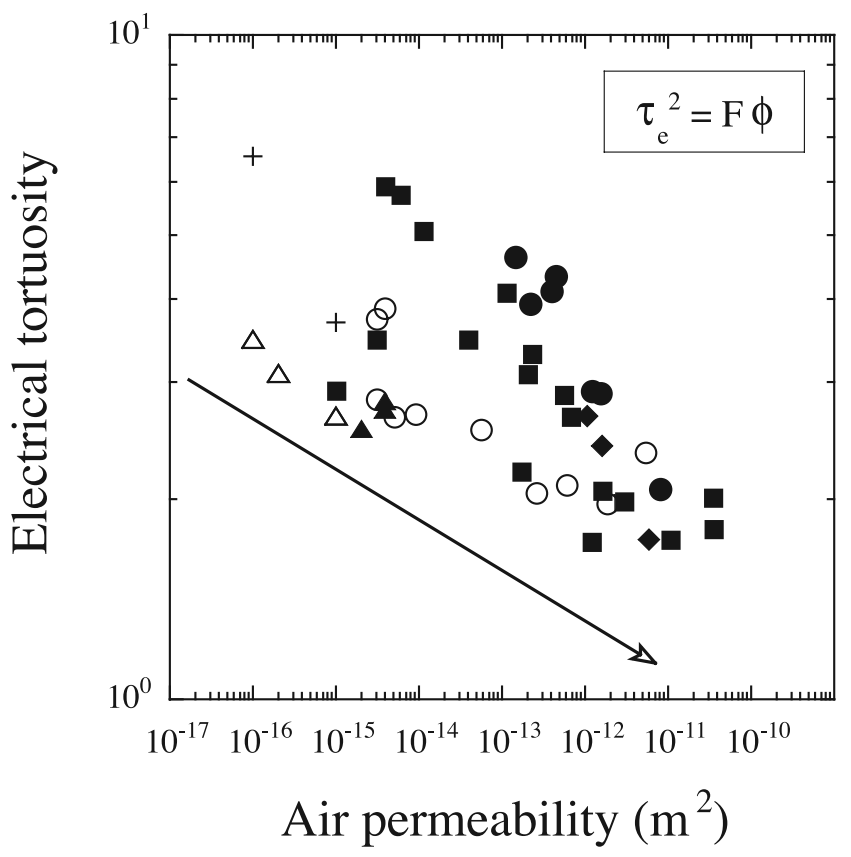

Figure 10. Electrical tortuosity deduced from electrical measurements as a function of permeability. The symbol description is given in Figure 3. The arrow shows a general decreasing trend of tortuosity with increasing permeability. 


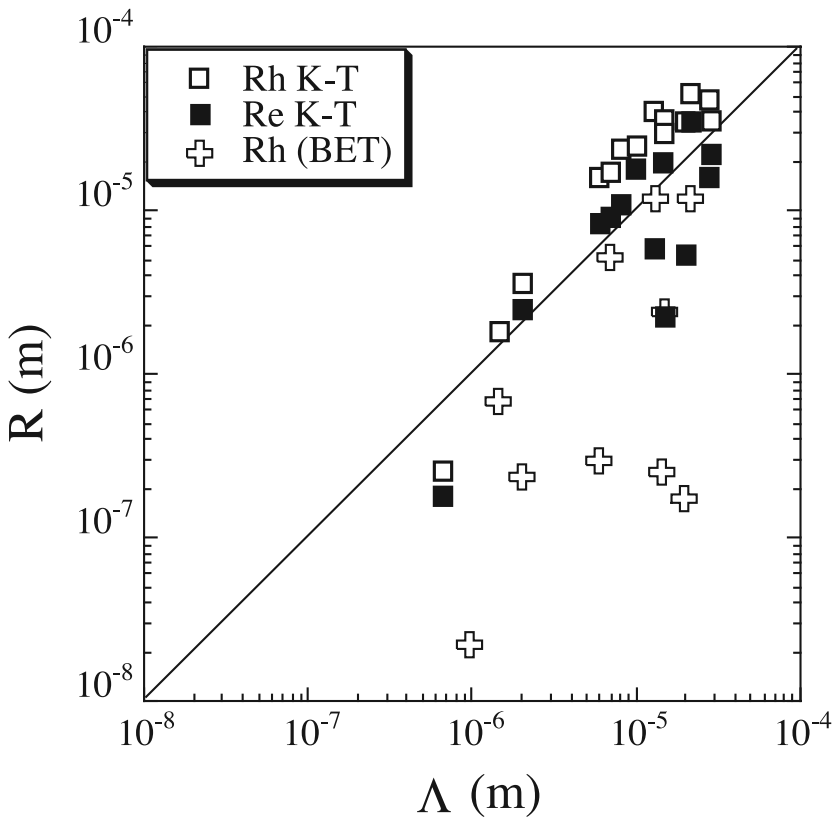

Figure 11. Comparison between different characteristics lengths controlling transport properties. $\Lambda$ is computed using the Johnson and Schwartz [1989] model. $\mathrm{R}_{\mathrm{h}}$ BET is deduced from BET measurement. Rh K-T and Re K-T are estimated from $\mathrm{H}_{\mathrm{g}}$ porosimetry experiment and correspond to $\mathrm{R}_{\mathrm{h}}^{\max }$ and $\mathrm{R}_{\mathrm{e}}^{\max }$, the two characteristic radius introduced by Katz and Thompson [1987].

[1989] consider that $\Lambda$ is a good estimation of the mean hydraulic radius $R_{h}$ and show that

$$
\Lambda=\sqrt{8 k F} .
$$

[68] Figure 11 compares this length to those deduced from BET $\left(\mathrm{R}_{\mathrm{h}}^{\mathrm{BET}}\right)$ and $\mathrm{Hg}$ porosimetry $\mathrm{R}_{\max }^{\mathrm{h}}$ and $\mathrm{R}_{\max }^{\mathrm{e}}$ measurements and shows that $R_{h}^{\max } \geq \Lambda \geq R_{e}^{\max } \geq R_{h}^{B E T}$, in general. $\Lambda$ ranges from 1 to $30 \mu \mathrm{m}$ in the pyroclastic rock samples. Mean hydraulic radii deduced from BET measurements are smaller than those deduced from $\mathrm{Hg}$ porosimetry. This can partly explain the permeability underestimation observed in the samples using the CK model (see section 5.1). The BET measurements provide the entire pore surface connected to the exterior and then include the surface of "dead end" pore channels not useful for fluid flow through the two ends of the cylindrical samples. Therefore $R_{h}$ is underestimated by this method.

\subsection{Relations Between the Transport Properties of Montagne Pelée Rocks and the Magma Degassing Conditions at Depth}

[69] The hydraulic and electrical properties measured at laboratory scale on a large sampling of pyroclastic rocks from Montagne Pelée confirm the fundamental difference in the pore geometry of pumices compared to the other pyroclastic products (scoria, lava blocks from block-andash flows and Peléean nuées ardentes, lava domes and lava flows). These differences in transport properties are consistent with the eruptive mechanisms proposed to explain the two main eruptive styles on Montagne Pelée volcano: (1) dome-forming eruptions and associated block-and-ash flow and/or Peléean nuées ardentes; and (2) Plinian eruption which generated ash-and-pumice fallouts and flows. These two styles of activity occurred generally separately but in some case can be produced during the same event. Indeed, several eruptions of Montagne Pelée show transitions from explosive to effusive eruptive styles. Transitions from effusive to explosive styles are more rarely observed but occurred also as, for example, during the P1 eruption (650 years B.P.). This cannot be attributed to differences in the preeruptive conditions, according to the relative homogeneity of the mineralogical and chemical (trace and major elements) compositions of all erupted magma [Villemant et al., 1996; Villemant and Boudon, 1998]. The explosive-effusive transition is generally attributed to the progressive loss of volatile from magma stored in superficial reservoir, which leads to the evolution from a closed to an open system of degassing [Villemant and Boudon, 1998; Villemant et al., 2003]. The effusive-explosive transition is explained by involving an interaction between the magma and the surrounding fluids [Jaupart and Allègre, 1991; Jaupart and Tait, 1995; Jaupart, 1996; Villemant and Boudon, 1998].

[70] The important porosities associated with relatively low permeabilities, the existence of an unconnected porosity and the absence of large pore access radii observed on pumices are consistent with the hypothesis that during Plinian eruptions the interaction between the magma and the surrounding rocks is limited (closed system evolution). In the same way, the relatively high permeabilities observed in the lava blocks from block-and-ash flow and Peléean nuées ardentes generated by dome-forming eruptions, despite their weaker porosities and their pore tortuosities comparable or higher than in pumices, is in good agreement with an evolution in which the magma interacts with the exterior (open system evolution). In this case the degassing is more important, the bubbles interact strongly and the pores apertures observed in the erupted rocks are larger. Poorly to nonvesiculated lava blocks result from more complex and variable degassing processes that for Plinian products [Martel et al., 2000a, 2000b] and have more heterogeneous pore structures. That may explain the wide range of transport properties measured in these samples. On the scoria, the vesiculation processes are certainly similar to those of pumices, but as the magma composition is more basic and then more fluid, the degassing is facilitated [Mangan et al., 1993; Mangan and Cashman, 1996]. This explains the more important permeabilities of these rocks compared to pumices and the absence of a unconnected porosity. The other samples (lavas and lava domes) are highly degassed products and theirs porosity and permeability are small. In addition, the electrical measurements show they may contain more cracks than the other lithologies.

\subsection{Preliminary Comparison to Field Data on Montagne Pelée Volcano}

[71] The pyroclastic deposits are a mixture, more or less consolidated, of ashes and lava blocks similar to those used in this study. At the field scale, their bulk properties may be different to those measured in the laboratory on individual block. The effects of in situ conditions (pressure, temperature, compaction), macroscale fracturing or strong discontinuities, as well as weathering can play an important role on fluid transport and diffusion processes at the field scale 
[Brace, 1984; Guéguen et al., 1996; Fisher, 1998; Flint and Selker, 2003; Sruoga et al., 2004]. Therefore the relation between the transport properties at field and laboratory scales may not be obvious. We try to compare our laboratory results to sparse field data on hydrogeologic properties of Montagne Pelée deposits. Westercamp and Traineau [1987] performed electrical measurements along the western flank of Montagne Pelée and report average resistivity in permeable pyroclastic deposits ranging between 200 and $900 \Omega \mathrm{m}$. The electrical resistivity of fluids measured on boreholes at Montagne Pelée ranges from 20 to $72 \Omega \mathrm{m}\left(\sigma_{f} \sim\right.$ 15 to $50 \mathrm{mS} \mathrm{m}^{-1}$ ) [Barat, 1984]. For such conductivities of the fluid and an average formation factor of 35 deduced from the electrical measurements on the recent deposits (third stage), presented in section 4.4 , we estimate that rock conductivities $\sigma_{r}\left(\sim \sigma_{\mathrm{f}} / \mathrm{F}\right)$ range from 0.43 to $1.43 \mathrm{mS} \mathrm{m}^{-1}$ that corresponds to resistivities between 2 and $700 \Omega \mathrm{m}$. These values are comparable to the above field data.

[72] Concerning the hydraulic characteristics of Montagne Pelée deposits, Barat [1984] presents some measurements of hydraulic transmissivity in few shallow boreholes ( $\sim 50 \mathrm{~m}$ depth) drilled on Montagne Pelée flanks. The transmissivity (permeability coefficient, $K_{f}$, multiplied by the layer thickness) measured in about 50-m layers of these deposits is $\sim 10^{-3}-10^{-2} \mathrm{~m}^{2} \mathrm{~s}^{-1}$. This corresponds to highly permeable media. The infiltrations of meteoritic water are in fact important in the edifice, particularly in the recent deposits formed by ash-and-pumice falls and flows, blockand-ash flows and scoria flows.

[73] A permeability of $10^{-12} \mathrm{~m}^{2}$ corresponds to a $K_{f}$ value of about $10^{-5} \mathrm{~m} \mathrm{~s}^{-1}$ [see Schön, 1996]. Then, the corresponding water permeability for the recent deposits of Montagne Pelée should range from 2 to $20 \times 10^{-12} \mathrm{~m}^{2}$, which values are greater than the air permeability observed on laboratory data. The transfer from the laboratory to the field needs more extensive investigations. To this purpose we performed preliminary electrical and hydraulic measurements on a $30 \mathrm{~cm}$ in length and $10 \mathrm{~cm}$ in diameter cylindrical sample composed by an unconsolidated mixture of ashes and porous lava blocks from Montagne Pelée deposits. The results still to be deeply analyzed. The scaling issues are important for a correct integration of rock physic results based on laboratory measurements in geophysical investigations at the field scale.

\section{Conclusion}

[74] The selected pyroclastic rocks present similar chemical and mineralogical compositions but the characteristics of their pore microstructure show notable variability. We observed a wide range of porosity, permeability ( 6 orders of magnitude), pore access radii and formation factor. Pumices have the higher porosity but a relatively low degree of bubble connectivity since most of these samples have more than $10 \%$ of isolated pores and relatively low permeability according to their high porosity. By contrast, vesiculated to nonvesiculated lava blocks from block-and-ash flow and Peléean nuées ardentes deposits have high permeability associated to better interconnected pores. The different hydraulic properties obtained on lava blocks and pumices from pyroclastic deposits of Montagne Pelée confirm that the mechanisms of degassing and vesiculation are different for the two main types of eruptions that lead to their formation.

[75] The relative weak correlation between connected porosity and permeability, or formation factor, in pyroclastic rocks suggests that only a small volume of the pore network participates to the hydraulic and electrical transport. In particular, the transport properties of pumices are control by their small pore entrance, a fine pore space characteristic.

[76] The formation factor and the permeability are relatively well correlated bulk properties of pyroclastic rocks, compared to observations in sedimentary rocks. This correlation is useful for predicting the difficult to measure hydraulic properties using electrical properties that are easily measured.

[77] The electrical and hydraulic properties of pyroclastic rocks aid to interpret their pore microstructure in terms of dynamical processes, which occur during ascent, vesiculation and fragmentation of silicic magmas. In very low porosity samples, the gas escape may occur predominantly through microcracks. At high porosities, the influence of vesicles becomes progressively stronger as they form an increasingly connected network. As a result, the models based on the percolation concepts, as Katz and Thompson model, are better adapted than the equivalent channel model of Carman-Kozeny to interpret the transport properties of pyroclastic rocks. An interconnected network is required for hydraulic or electrolytic charge transport. Critical pore radius associated to $\mathrm{Hg}$ porosimetry (KT model) is a good characteristic length scale for transport properties of pyroclastic rocks. The pore fabric causes notable anisotropy of the hydraulic and electrical conductivity in these rocks.

[78] Electrical conductivity measurements of fluidsaturated porous rocks are sensitive to the interconnectivity and tortuosity of the pore space and thus provide additional information that relates to permeability. This study proposed a set of relations between hydraulic and electrical properties for pyroclastic rocks that provide a basis for a realistic understanding of relations between hydrologic properties and geophysical processes on volcanoes. However, we need to address carefully scaling issues, before any attempt to use these results to improve field investigations on Montagne Pelée or similar volcanoes.

[79] Acknowledgments. We are grateful to Benoit Villemant, JeanChristophe Komorowski, and the staff of the Montagne Pelée volcano Observatory for their help during the rock sampling. Benoit Villemant kindly gave us the SEM images in Figure 2. We thank Bernard Zinszner and Michel Masson from the Rocks Physics laboratory of the Institut Francais du Petrole (France) for their technical assistance on permeability measurements and Jean-Baptiste Clavaud for fruitful discussions. We also thank the Associate Editor, André Revil, and the reviewers, Ernst Huenges and Teng-Fong Wong, for very helpful comments. This study was supported by the French National Research Council CNRS-INSU-PNRN and the EEC work program "Environmental and Climate-Volcanic risk." IPG contribution 2173 .

\section{References}

Adler, P. M. (1992), Porous Media: Geometry and Transports, Elsevier, New York.

Archie, G. E. (1942), The electrical resistivity log as aid in determining some reservoir characteristics, Trans. Am. Inst. Mineral. Meteorol., 146, $54-62$.

Barat, A. (1984), Etude du rôle des eaux souterraines dans le mécanisme des éruptions phréatiques: Application à la Montagne Pelée de Martinique et à la Soufrière de Guadeloupe, Ph.D. thesis, 232 pp., Univ. Michel de Montaigne Bordeaux III, Pessac, France.

Berkowitz, B., and R. P. Ewing (1998), Percolation theory and network modeling applications in soil physics, Surv. Geophys., 19, 23-72. 
Bernabé, Y. (1998), Streaming potential in heterogeneous networks, J. Geophys. Res., 103, 20,827-20,841.

Bernabé, Y., W. F. Brace, and B. Evans (1982), Permeability, porosity and pore geometry of hot pressed calcite, Mech. Mater, 1, 173-183.

Bernard, M. L. (1999), Etude expérimentale des propriétés physiques des roches pyroclastiques de la Montagne Pelée, Ph.D. thesis, 260 pp., Univ. of Paris VII, Paris.

Blower, J. D. (2001), A three-dimensional network model of permeability in vesicular material, Comput. Geosci., 27, 115-119.

Blower, J. D., J. P. Keating, H. M. Mader, and J. C. Phillips (2001), Inferring volcanic degassing processes from vesicle size distribution, Geophys. Res. Lett., 28, 347-350.

Blower, J. D., J. P. Keating, H. M. Mader, and J. C. Phillips (2002), The evolution of bubble size distribution in volcanic eruptions, J. Volcanol. Geotherm. Res., 120, 1-23.

Boudon, G., and J. Lajoie (1989), The 1902 peléan deposits in the Fort Cemetery of St Pierre, Martinique: A model for the accumulation of turbulent nuées ardentes, J. Volcanol. Geotherm. Res., 43, 359-364.

Boudon, G., A. Le Friant, B. Villemant, and J.-P. Viodé (2005), Martinique, in Volcanic Atlas of the Lesser Antilles, edited by J. M. Lindsay et al., pp. 130-149, Seismic Res. Unit, Univ. of the West Indies, Trinidad and Tobago.

Bourbié, T., and B. Zinszner (1985), Hydraulic and acoustic properties as a function of porosity in Fontainbleau sandstone, J. Geophys. Res., 90, $11,524-11,532$.

Bourdier, J. L., A. Gourgaud, and P. M. Vincent (1985), Magma mixing in a main stage of formation of Montagne Pelée: The Saint-Vincent type scoria flow sequence (Martinique, F. W. I), J. Volcanol. Geotherm. Res., 25, 309-332.

Bourdier, J. L., G. Boudon, and A. Gourgaud (1989), Stratigraphy of the 1902 and 1929 nuée ardente deposits, Mount Pelée, Martinique, J. Volcanol. Geotherm. Res., 38, 77-96.

Brace, W. F. (1984), Permeability of crystalline rocks: New in situ measurements, J. Geophys. Res., 89, 4327-4330.

Brown, R. J. S. (1980), Connection between formation factor for electrical resistivity and fluid-solid coupling factor in Biot's equations for acoustic waves in fluid-filled porous media, Geophysics, 45, 1269-1275.

Carman, P. C. (1956), Flow of Gases Through Porous Media, Elsevier, New York.

Clavier, C., G. Coates, and J. Dumanoir (1977), The theoretical and experimental bases for "dual water" model for the interpretation of shaly sands, paper presented at 52nd Annual Fall Technical Conference and Exhibition, Soc. of Pet. Eng., Denver, Colo.

David, C. (1993), Geometry of flow paths for fluid transport in rocks, J. Geophys. Res., 98, 12,267-12,278.

David, C., Y. Guéguen, and G. Pampoukis (1990), Effective medium theory and network theory applied to the transport properties of rocks, J. Geophys. Res., 95, 6993-7005.

Del Negro, C., F. Ferrucci, and R. Napoli (1997), Retrieval of large volcanomagnetic effects observed during the 1981 eruption of Mt. Etna, Ann. Geophys., 40, 547-562.

Dullien, F. A. (1992), Porous Media: Fluid Transport and Pore Structure, 2nd ed., Elsevier, New York.

Eichelberger, J. C., C. R. Carrigan, H. R. Westrich, and R. H. Price (1986), Non-explosive rhyolite volcanism, Nature, 323, 598-602.

Feng, S., B. I. Halperin, and P. N. Sen (1987), Transport properties of continuum systems near the percolation threshold, Phys. Rev. B, 35, $197-214$.

Fichaut, M., R. C. Maury, H. Traineau, D. Westercamp, J. L. Joron, A. Gourgaud, and C. Coulon (1989), Magmatology of Mount Pelée (Martinique, F.W.I.). III: Fractional crystallization versus magma mixing, J. Volcanol. Geotherm. Res., 38, 189-212.

Fisher, A. T. (1998), Permeability within basaltic oceanic crust, Rev. Geophys., $36,143-182$.

Flint, L. E. (2003), Physical and hydraulic properties of volcanic rocks from Yucca Mountain, Nevada, Water Resour. Res., 39(5), 1119, doi:10.1029/ 2001WR001010.

Flint, L. E., and J. S. Selker (2003), Use of porosity to estimate hydraulic properties of volcanic tuffs, Adv. Water Resour., 26, 561-571.

Gardner, J. E., R. M. Thomas, C. Jaupart, and S. Tait (1996), Fragmentation of magma during Plinian volcanic eruptions, Bull. Volcanol., 58, 144-162.

Géraud, Y. (1991), Déformation thermomécanique et porosité des roches granitiques: Evolution de l'espace poreux, Ph.D. thesis, 329 pp., Univ. of Marseille, Marseille, France.

Gourgaud, A., M. Fichaut, and J. L. Joron (1989), Magmatology of Mt Pelée (Martinique, F.W.I.), I: Magma mixing and triggering of the 1902 and 1929 Pelean nuées ardentes, J. Volcanol. Geotherm. Res., 38, 143-170.

Guéguen, Y., P. Gravrilenko, and M. Le Ravalec (1996), Scales of rock permeability, Surv. Geophys., 17, 245-263.
Gunn, B. M., M. J. Roobol, and A. L. Smith (1974), Petrochemistry of the pelean-type volcanoes of Martinique, Geol. Soc. Am. Bull., 85, $1023-$ 1030 .

Hashimoto, T., and Y. Tanaka (1995), A large self-potential anomaly on Unzen volcano, Shimabara peninsula, Kyushu, Japan, Geophys. Res. Lett., 22, $193-194$.

Ishido, T., and Y. Mizutani (1981), Experimental and theoretical basis of electrokinetic phenomena in rock-water systems and its application to geophysics, J. Geophys. Res., 86, 1763-1775.

Jaupart, C. (1996), Physical models of volcanic eruptions, Chem. Geol. $128,217-227$.

Jaupart, C., and C. J. Allègre (1991), Gas content, eruption rate and instabilities of eruption regime in silicic volcanoes, Earth Planet. Sci. Lett., 102, 413-429.

Jaupart, C., and S. Tait (1995), Dynamics of differentiation in magma reservoirs, J. Geophys. Res., 100, 17,615-17,636.

Johnson, D. L., and L. M. Schwartz (1989), Unified theory of geometrical effects in transport properties of porous media, paper presented at SPWLA Thirtieth Annual Logging Symposium, Soc. of Petrophys. and Well Log Anal., Denver, Colo.

Johnson, D. L., and P. N. Sen (1988), Dependence of the conductivity of a porous medium on electrolyte conductivity, Phys. Rev. B, 37, 3502-3510.

Johnson, D. L., J. Koplik, and L. M. Schwartz (1986), New pore-size parameter characterizing transport in porous media, Phys. Rev. Lett., $57,2564-2567$

Johnson, D. L., J. Koplik, and R. Dashen (1987), Theory of dynamic permeability and tortuosity in fluid-saturated porous media, J. Fluid Mech., 176, 379-402.

Johnson, M. J. S., and F. D. Stacey (1969), Volcanomagnetic effect observed on Mt. Ruapehu, New Zealand, J. Geophys. Res., 74, 6541-6544.

Jouniaux, L., M. L. Bernard, M. Zamora, and J. P. Pozzi (2000), Streaming potential in volcanic rocks from Mount Pelée, J. Geophys. Res., 105, $8391-8401$

Kaminski, E., and C. Jaupart (1998), The size distribution of pyroclasts and the fragmentation sequence in explosive volcanic eruptions, J. Geophys. Res., 103, 29,759-29,779.

Kan, R., and P. N. Sen (1987), Electrolytic conduction in periodic arrays of insulators with charges, J. Chem. Phys., 86, 5748-5756.

Katz, A. J., and A. H. Thompson (1986), A quantitative prediction of permeability in porous rock, Phys. Rev. B, 24, 8179-8181.

Katz, A. J., and A. H. Thompson (1987), Prediction of rock electrical conductivity from mercury injection measurements, J. Geophys. Res., 92, 599-607.

Keller, G. V. (1989), Electrical properties, in Practical Handbook of Physical Properties of Rocks and Minerals, edited by R. S. Carmichael, pp. 217-294, CRC Press, Boca Raton, Fla.

Kirkpatrick, S. (1973), Percolation and conduction, Rev. Mod. Phys., 45, $574-588$.

Klug, C., and K. V. Cashman (1994), Vesiculation of May 18, 1980, Mount St. Helens magma, Geology, 22, 468-472.

Klug, C., and K. V. Cashman (1996), Permeability development in vesiculating magma, Bull. Volcanol., 58, 87-100.

Klug, C., K. V. Cashman, and C. R. Bacon (2002), Structure and physical characteristics of pumice from the climatic eruption of Mount Mazana (Crater Lake), Oregon, Bull. Volcanol., 64, 468-501.

Lacroix, A. (1904), La Montagne Pelée et Ses Eruptions, 662 pp., Masson, Paris.

Le Friant, A., G. Boudon, C. Deplus, and B. Villemant (2003), Large scale flank collapse events during the activity of Montagne Pelée, Martinique, Lesser Antilles, J. Geophys. Res., 108(B1), 2055, doi:10.1029/2001JB001624.

Le Pennec, J., D. Hermitte, I. Dana, P. Pezard, C. Coulon, J. Cochemé, E. Mulyadi, F. Ollagnier, and C. Revest (2001), Electrical conductivity and pore-space topology of Merapi lavas: Implications for the degassing of porphyritic andesite magmas, Geophys. Res. Lett., 28, 4283-4286.

Malengrau, B., J.-F. Lénat, and A. Bonneville (1994), Cartography and temporal observation of self-potential (SP) anomalies at Piton de la Fournaise, Bull. Soc. Geol. Fr., 165, 221-232.

Mangan, M. T., and K. V. Cashman (1996), The structure of basaltic scoria and reticulite and inferences for vesiculation, foam formation, and fragmentation in lava fountains, J. Volcanol. Geotherm. Res., 73, 1-18.

Mangan, M. T., K. V. Cashman, and S. Newman (1993), Vesiculation of basaltic magma during eruption, Geology, 21, 157-160.

Martel, C., M. Pichavant, J. L. Bourdier, H. Traineau, F. Holtz, and B. Scaillet (1998), Magma storage conditions and control of eruption regime in silicic volcanoes: Experimental evidence from Mt. Pelée, Earth Planet. Sci. Lett., 156, 89-99.

Martel, C., J. L. Bourdier, M. Pichavant, and H. Traineau (2000a), Textures, water content and degassing of silicic andesites from recent Plinian and dome-forming eruptions at Mount Pelée volcano (Martinique, Lesser Antilles arc), J. Volcanol. Geotherm. Res., 96, 191-206. 
Martel, C., D. B. Dingwell, O. Spieler, M. Pichavant, and M. Wilke (2000b), Fragmentation of foamed silicic melts: An experimental study, Earth Planet. Sci. Lett., 178, 47-58.

Mavko, G., and A. Nur (1998), The effect of a percolation threshold in the Kozeny-Carman relation, Geophysics, 62, 1480-1482.

Melnik, O., and R. S. J. Sparks (2002), Dynamic of magma ascent and lava extrusion at Soufriere Hills volcano, Montserrat, in The Eruption of Soufriere Hills Volcano, Montserrat, From 1995-1999, edited by T. Druitt and B. Kokelaar, Mem. Geol. Soc. London, 22, 153-171.

Michel, S., and J. Zlotnicki (1998), Self-potential and magnetic survey of La Fournaise volcano (Réunion island): Correlation with faulting, fluid circulation, and eruption, J. Geophys. Res., 103, 17,845-17,857.

Pape, H., L. Riepe, and J. R. Schopper (1981), Calculating permeability from surface area measurements, paper presented at Seventh European Logging Symposium, Soc. of Petrophys. and Well Log Anal., Paris.

Pape, H., L. Riepe, and J. R. Schopper (1982), A pigeon-hole model for relating permeability to specific surface, Log Anal., 23, 5-13. (Errata, Log Anal., 23, 50.)

Pape, H., L. Riepe, and J. R. Schopper (1984), Calculating permeability from electrical logging data, paper presented at 9th International Formation Evaluation Symposium, Soc. of Petrophys. and Well Log Anal., Paris.

Pape, H., L. Riepe, and J. R. Schopper (1987), Interlayer conductivity of rocks: A fractal model of interface irregularities for calculating interlayer conductivity of natural porous mineral systems, Colloids Surf., 27, 97-122.

Pape, H., C. Clauser, and J. Iffland (1999), Permeability prediction based on fractal pore-space geometry, Geophysics, 64, 1447-1460.

Perret, F. A. (1935), The Eruption of Mt. Pelée, 1929-1932, 126 pp., Carnegie Inst. of Washington, Washington, D. C

Pezard, P. A., et al. (1990), Downhole images: Electrical scanning reveals the nature of subsurface oceanic crust, Eos Trans. AGU, 71, 709.

Pichavant, M., C. Martel, J. Bourdier, and B. Scaillet (2002), Physical conditions, structure, and dynamics of a zoned magma chamber: Mount Pelée (Martinique, Lesser Antilles arc), J. Geophys. Res., 107(B5), 2093, doi:10.1029/2001JB000315

Pozzi, J. P., J. L. Le Mouël, J. C. Rossignol, and J. Zlotnicki (1979), Magnetic observations made on la Soufrière volcano (Guadeloupe) during the 1976-1977 crisis, J. Volcanol. Geotherm. Res., 5, 217-237.

Rabaute, A., B. Yven, W. Chelini, and M. Zamora (2003), Subsurface geophysics of the Phlegrean Fields: New insights from downhole measurements, J. Geophys. Res., 108(B3), 2171, doi:10.1029/2001JB001436.

Revil, A., and P. W. J. Glover (1998), Nature of surface electrical conductivity in natural sands, sandstones, and clays, Geophys. Res. Lett., 25, 691-694.

Revil, A., L. M. Cathles, S. Losh, and J. A. Nunn (1998), Electrical conductivity in shaly sands with geophysical applications, J. Geophys. Res., $103,23,925-23,936$.

Revil, A., D. Hermitte, E. Spangenberg, and J. J. Cochemé (2002), Electrical properties of zeolitized volcaniclastic materials, J. Geophys. Res., 107(B8), 2168, doi:10.1029/2001JB000599.

Revil, A., G. Saracco, and P. Labazuy (2003), The volcano-electric effect, J. Geophys. Res., 108(B5), 2251, doi:10.1029/2002JB001835.

Roobol, M. J., and A. L. Smith (1976), Mount Pelée, Martinique: A pattern of alternating eruptive styles, Geology, 4, 521-524.

Rust, A. C., and K. V. Cashman (2004), Permeability of vesicular silicic magma: Inertial and hysteresis, Earth Planet. Sci. Lett., 228, 93-107.

Saar, M. O., and M. Manga (1999), Permeability-porosity relationship in vesicular basalts, Geophys. Res. Lett., 26, 111-114.

Saar, M. O., and M. Manga (2002), Continuum percolation for randomly oriented soft-core prisms, Phys. Rev. E, 65, 056131, doi:10.1103/ PhysRevE.65.056131.

Sahimi, M. (1994), Applications of Percolation Theory, Taylor and Francis, Philadelphia, $\mathrm{Pa}$

Sasai, Y., et al. (1990), Volcanomagnetic effect observed during the 1986 eruption of Izu-Oshima volcano, J. Geomagn. Geoelectr. 42, 291-318.

Schön, J. H. (1996), Handbook of Geophysical Exploration: Seismic Exploration, vol. 18, Physical Properties of Rocks: Fundamentals and Principles of Petrophysics, 575 pp., edited by K. Helbig and S. Treitel, Elsevier, New York.

Schopper, J. R. (1982), Porosity and permeability, in Physical Properties of Rocks, Landolt-Börnsten: Numer. Data Funct. Relat. Sci. Technol., New Ser., vol. 1A, pp. 184-266, Springer, New York.

Schwartz, L. M., P. N. Sen, and D. L. Johnson (1989), Influence of rough surfaces on electrolytic conduction in porous media, Phys. Rev. B, 40, $2450-2458$

Sparks, R. S. J. (1978), The dynamics of bubble formation and growth in magmas: A review and analysis, J. Volcanol. Geotherm. Res., 3, 1-37.

Sparks, R. S. J., and S. Brazier (1982), New evidence for degassing process during explosive eruptions, Nature, 295, 218-220.

Sruoga, P., N. Rubinstein, and G. Hinterwimmer (2004), Porosity and permeability in volcanic rocks: A case study on the Serie Tobifera, South Patagonia, Argentina, J. Volcanol. Geotherm. Res., 132, 31-43.
Tait, S., R. Thomas, J. Gardner, and C. Jaupart (1998), Constraints on cooling rates and permeabilities of pumice in an explosive eruption from colour and magnetic mineralogy, J. Volcanol. Geotherm. Res., 86, 79-91. Tarantola, A. (1987), Inverse Problem Theory: Methods for Data Fitting and Model Parameter Estimation, 613 pp., Elsevier, New York.

Thomas, N., C. Jaupart, and S. Vergniolle (1994), On the vesicularity of pumices, J. Geophys. Res., 99, 15,633-15,644.

Traineau, H., D. Westercamp, and Y. Benderitter (1989), Case study of a volcanic geothermal system, Mount Pelée, Martinique, J. Volcanol. Geotherm. Res., 38, 49-66.

Vanorio, T., M. Prasad, D. Patella, and A. Nur (2002), Ultrasonic velocity measurements in volcanic rocks: Correlation with microtexture, Geophys. J. Int., 149, 22-36.

Villemant, B., and G. Boudon (1998), Transition from dome-forming to Plinian eruptive styles controlled by $\mathrm{H}_{2} \mathrm{O}$ and $\mathrm{Cl}$ degassing, Nature, 392, 65-69.

Villemant, B., G. Boudon, and J. C. Komorowski (1996), U-series disequilibrium in arc magmas induced by water magma interaction, Earth Planet. Sci. Lett., 140, 259-267.

Villemant, B., G. Boudon, S. Nougrigat, S. Poteaux, and A. Michel (2003), Water and halogens in volcanic clasts: Tracers of degassing processes during Plinian and dome-building eruptions, in Volcanic Degassing, edited by C. Oppenheimer, D. M. Pyle, and J. Barclay, Geol. Soc. Spec. Publ., 213, 63-79.

Vincent, P. M., J. L. Bourdié, and G. Boudon (1989), The primitive volcano of Mount Pelée: Its construction and partial destruction by flank collapse, J. Volcanol. Geotherm. Res., 38, 1-15.

Waxman, M. H., and L. J. M. Smits (1968), Electrical conductivities in oilbearing shaly sands, Soc. Pet. Eng. J., 8, 107-122.

Westercamp, D. (1976), Petrology of the volcanic rocks of Martinique, West Indies, Bull. Volcanol., 39, 175-200.

Westercamp, D., and H. Traineau (1983), The past 5,000 years of volcanic activity at Mt Pelée, Martinique (F.W.I): Implications for volcanics hazards, J. Volcanol. Geotherm. Res., 17, 159-186.

Westercamp, D., and H. Traineau (1987), Schéma hydrologique et géothermique d'un stratovolcan d'arc insulaire: Exemple de la Montagne Pelée, Martinique (Antilles françaises), Bull. Soc. Geol. Fr., 8, 1063-1073.

Whitham, A. G., and R. S. J. Sparks (1986), Pumice, Bull. Volcanol, 48 , 209-223

Wong, P., J. Koplik, and J. P. Tomanic (1984), Conductivity and permeability of rocks, Phys. Rev. B, 30, 6606-6614.

Yven, B. (2001), Minéralogie, microstructure et propriétés physiques des roches volcaniques des Champs Phlégréens (Italie), Ph.D. thesis, 340 pp. Univ. of Paris VII, Paris.

Zlotnicki, J., and J. L. Le Mouël (1988), Volcanomagnetic effects observed on Piton de la Fournaise volcano (Reunion island): 1985-1987, J. Geophys. Res., 93, 9156-9171.

Zlotnicki, J., and J. L. Le Mouël (1990), Possible electrokinetic origin of large magnetic variations at La Fournaise volcano, Nature, 343, 633-636.

Zlotnicki, J., R. Verhille, J. C. Delmond, G. Simon, and P. Guillement (1986), Magnetic network on Montagne Pelée volcano (Martinique, Lesser Antilles): A trial to discriminate volcanomagnetic signal, J. Geomagn. Geoelectr., 38, 151-164.

Zlotnicki, J., M. G. Moreau, and J. P. Viodé (1987), Volcanomagnetic variation related to the seismic crisis that occurred from December 1985 through May 1986 on Montagne Pelée, Martinique (Lesser Antilles), J. Geomagn. Geoelectr., 39, 487-500.

Zlotnicki, J., J. L. Le Mouël, J. C. Delmond, C. Pambrun, and H. Delorme (1993), Magnetic variations on Piton de la Fournaise volcano: Volcanomagnetic signals associated with the November 6 and 30, 1987, eruptions, J. Volcanol. Geotherm. Res., 56, 281-296.

Zlotnicki, J., G. Boudon, J. P. Viodé, J. F. Delarue, and A. Mille (1998), Hydrothermal circulation beneath Mount Pelée inferred by self potential surveying: Structural and tectonic implications, J. Volcanol. Geotherm. Res., 84, 73-91.

M.-L. Bernard, Département de Géophysique, Institut Français du Pétrole, 1-4 Avenue Bois-Préau, F-92852 Rueil-Malmaison Cedex, France. (m-lise.bernard@ifp.fr)

G. Boudon, Equipe de Volcanologie, Institut de Physique du Globe de Paris, CNRS UMR4 7154, 4 Place Jussieu, F-75252 Paris Cedex 05, France.

Y. Géraud, Institut de Physique du Globe de Strasbourg, 1 rue Blessig, F-67086 Strasbourg, France.

M. Zamora, Equipe Géomatériaux et Environnement, Institut de Physique du Globe de Paris, CNRS UMR4 7154, 4 Place Jussieu, F-75252 Paris Cedex 05, France. 